\title{
The impact of public employment: Evidence from Bonn ${ }^{\text {is }}$
}

\author{
Sascha O. Becker ${ }^{\mathrm{a}, *}$, Stephan Heblich ${ }^{\mathrm{b}}$, Daniel M. Sturm ${ }^{\mathrm{c}}$ \\ ${ }^{a}$ Monash \& Warwick U, CAGE and CEPR, Australia \\ ${ }^{\mathrm{b}}$ University of Toronto, CEP, CESifo and ifw Kiel, Canada \\ ${ }^{\mathrm{c}}$ London School of Economics and CEPR, United Kingdom
}

\section{A R T I C L E I N F O}

\section{JEL classification:}

F15

J45

N44

R12

\section{Keywords:}

Economic geography

Public employment

Place-Based policies

German division

\begin{abstract}
A B S T R A C T
This paper evaluates the impact of changes in public employment on private sector activity using the creation of the new West German government in Bonn in the wake of the Second World War as a source of exogenous variation. To guide our empirical analysis, we develop a simple economic geography model in which public sector employment affects private sector employment through its impact on wages and house prices and also through potential productivity and amenity spillovers to the private sector. We find that relative to a control group of cities, Bonn experiences a substantial increase in public employment. However, this results in only modest increases in private sector employment with each additional public sector job destroying around 0.2 jobs in industry and creating just over one additional job in other parts of the private sector. We show how our model can explain this finding and provide several pieces of evidence for the mechanisms emphasized by the model.
\end{abstract}

\section{Introduction}

Following Krugman (1991), there has been a wave of research investigating the spatial distribution of economic activity. By and large, this literature has concentrated on the location choices of firms and workers in the private sector. However, in most advanced economies, a substantial share of the workforce is employed in the public sector. ${ }^{1}$ This is important for at least two reasons. First, the spatial distribution of public employment is unlikely to be determined exclusively by market forces. Indeed, many governments use public employment as a form of regional policy and create public sector jobs in economically lagging regions. ${ }^{2}$ Second, the distribution of public employment across locations should have important impacts on the location of private sector activity through its general equilibrium impact on wages and house prices and also through potential productivity and amenity spillovers from the public to the private sector.
In this paper we use the creation of the West German government in Bonn in the wake of the Second World War as a source of exogenous variation to evaluate the causal impact of public employment on the spatial distribution of private sector activity. This approach has a number of attractive features. First, the arrival of the federal government in Bonn was a large and plausibly exogenous shock to public employment, which was driven by factors that are unrelated to the local economic performance of Bonn. Second, we are able to follow the impact of this shock over several decades, which allows us to capture the long-run general equilibrium response to this shock. Third, we are able to provide a number of pieces of evidence on the mechanisms through which public and private sector employment interact.

To guide our empirical analysis we develop a simple theoretical model which builds on Helpman (1998) and Redding and Sturm (2008). In the model both private sector firms and the public sector demand labor across different cities. The public sector produces a global public

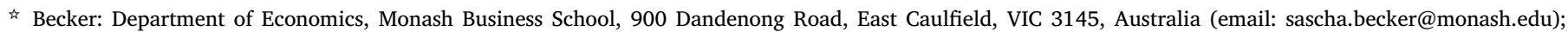

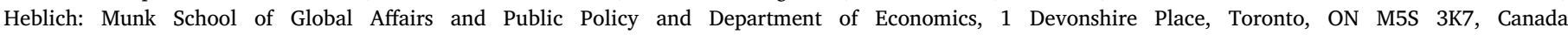

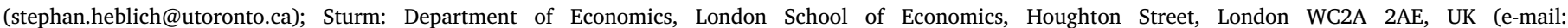

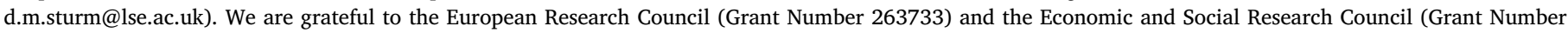

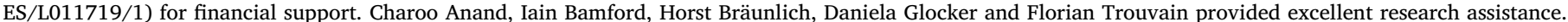

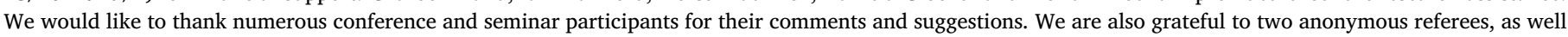

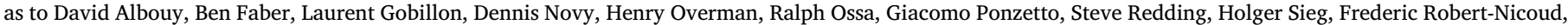
Jon Steinsson, Jonathan Vogel and Tony Venables for their comments and suggestions. The usual disclaimer applies.

* Corresponding author.

E-mail address: stephan.heblich@utoronto.ca (S. Heblich).

1 OECD (2009) reports that the share of public employment across OECD countries in 2005 ranges from highs close to $30 \%$ in Sweden and Norway to lows of less

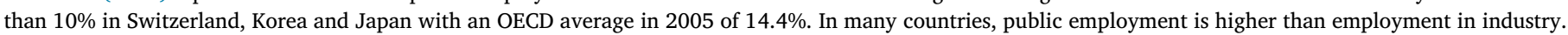

2 Alesina et al. (2001), for example, argue that in Italy public employment is mostly used as a re-distributive device from the richer North to the poorer South.
} 
good which enters the utility of all workers in the economy equally. The private sector consists of both a tradable and non-tradable sector. Firms in the tradable sector produce manufacturing varieties that are tradable across cities at some cost, while varieties produced by firms in the non-tradable sector can only be consumed locally. In the model the location of public employment affects the location choices of private sector workers through its impact on wages and house prices and also through potential productivity and amenity spillovers to the private sector.

Using panel data for Bonn and 40 control cities covering the period from 1925 to 1987, we examine the predictions of our model. The 40 control cities are the 20 cities ranked just above and just below Bonn in terms of total 1939 population. We employ both a differencein-differences comparison between Bonn and the control cities and also construct a synthetic control city for Bonn using the 40 control cities as the donor pool. Both approaches yield similar results and show that the substantial increase in public employment in Bonn has only resulted in modest increases in private sector employment. In particular, translating the estimated treatment effects from comparing Bonn to its synthetic control into employment multipliers we find that each additional public sector job reduces employment in industry by around 0.2 jobs and creates just over one additional job in other parts of the private sector.

We next show how this finding can be explained by our model and provide several pieces of evidence for the mechanisms emphasized by the model. First, we provide some suggestive direct evidence for the amenity and productivity spillovers from public to private employment that the model postulates. These results suggest that there could be amenity spillovers from public employment in Bonn, but there is little evidence for productivity spillovers. Second, we use data on wages and house prices to show that house prices are positively related to city size, as suggested by the model, while the expansion of public employment only had very small effects on nominal wages in Bonn by 1987 . Third, we undertake a simple quantitative analysis of the model to explore the parameter values for which the model can best fit the reduced form evidence. The quantitative analysis suggests that the increase in public employment has generated sizable amenity spillovers and if anything marginally negative productivity spillovers, which reinforces the reduced form evidence on mechanisms.

Our paper contributes to a number of literatures. The idea that expansions in employment in a tradable sector can have multiplier effects on employment in other sectors in the same location has a long history, with early contributions by Daly (1940), Hildebrand and Mace (1950) and Thompson (1959) (see Richardson (1985) for a survey of this early work). The early literature in this area uses simple crosssectional correlations or input-output approaches to estimate multipliers and struggles to isolate plausibly exogenous variation. To overcome these problems, Carrington (1996) uses the exogenous shock to employment caused by the construction of the Trans-Alaskan Pipeline between 1974 and 1977 on other parts of the Alaskan labor market. Similarly, Black et al. (2005) analyze the effect of the coal boom in the 1970s and the subsequent coal bust in the 1980s as an exogenous shock and estimate that each additional mining job created 0.17 non-tradable jobs, while the loss of a mining job implies a loss of 0.34 non-tradable jobs. Moretti (2010) uses a shift-share instrument to isolate exogenous variation in manufacturing employment across US cities. He estimates that an additional job in the tradable sector of a US city creates 1.6 additional jobs in the city's non-tradable sector, with a larger multiplier effect for additional skilled jobs. Recently, Feyrer et al. (2017) use the drilling of new wells during the US fracking boom to examine the spatial and sectoral dispersion of this shock.

While governments have some policy instruments to influence the spatial distribution of manufacturing and other tradable employment, they have direct control over the location of public employment and regularly use increases in public employment to support lagging regions. Surprisingly, there is little systematic evidence on the spillover effects of changes in the spatial distribution of public employment on the private sector. An important exception is Faggio and Overman (2014) who use a shift-share instrument to isolate exogenous variation in public employment across 325 UK local authorities covering the period 2003 to 2007. They find that increases in public sector employment have a small but statistically insignificant positive effect on overall private sector employment. Furthermore, they show that this overall effect can be decomposed into a decrease in employment in industry and increases in employment in non-tradable sectors.

Several papers have recently extended the work of Faggio and Overman (2014). Faggio (2019) uses a difference-in-differences approach on data covering 2003 to 2008 to evaluate relocations of public sector employment from London recommended by the Lyons Review, finding broadly similar results to Faggio and Overman (2014). Faggio et al. (2018) investigate whether the opening of federal ministries in Berlin in 1999 has resulted in faster private sector job creation in postcodes of Berlin that received a federal ministry relative to postcodes in other parts of Berlin. Auricchio et al. (2020) use a shift-share instrument similar to Faggio and Overman (2014) to estimate the effect of changes in public employment on private employment across Italian municipalities using data from the 2001 and 2011 censuses. JofreMonseny et al. (2020) simulate the impact of public on private employment in a search and matching model and also show reduced form evidence using Spanish data for 1980, 1990 and 2001. Our approach differs from Faggio and Overman (2014) and the subsequent literature in three main ways. First, we use a different source of plausibly exogenous variation that comes from a large scale natural experiment to estimate the impact of changes in public employment on the private sector. Second, we are able to observe the impact of this change in public employment over several decades. Third, we develop a simple theoretical model which can be calibrated to the reduced form evidence to shed light on the mechanisms through which public and private employment interact. $^{3,4}$

Our paper is also related to the wider literature following Rosen (1979) and Roback (1982) that examines amenity and productivity differences across locations. See, for example, Albouy and Lue (2015) for a recent contribution. While much of this literature has considered exogenous differences in amenities, many urban amenities are plausibly endogenously determined, as in Glaeser et al. (2001), Ahlfeldt et al. (2015) and Diamond (2016). We show that public employment is potentially an important channel of local amenity differences across cities. We also contribute to the wider literature on local labor market shocks. One strand of this literature investigates the impact of closures of military bases on local economic outcomes (see, for example, aus dem Moore and Spitz-Oener (2012) for evidence from Germany and Moretti (2011) for a recent survey). Finally, there is a growing literature that evaluates the effects of place-based policies. Recent contributions to this literature include Kline and Busso (2013) and Kline and Moretti (2014) (see, Neumark and Simpson (2015) for a recent survey).

The remainder of this paper is organized as follows. The next section develops a simple theoretical framework to guide our empirical analysis. Section 3 provides some historical background. Section 4 describes our data and Section 5 our empirical strategy. Section 6 presents our main empirical findings. Section 7 provides evidence for the mechanisms through which public and private employment interact. Section 8 puts our findings into perspective and draws out some implications, and the final section concludes.

\footnotetext{
${ }^{3}$ Boeri et al. (2000) and Algan et al. (2002) use panel data across a small set of OECD countries to estimate the impact of higher public employment on private employment at the country level. Although interesting, these estimates do not fully take into account adding-up constraints, or fully resolve the endogeneity problems surrounding public employment.

4 A further related literature uses spatial variation to provide new estimates of the government spending multiplier. See Acconcia et al. (2014) and Nakamura and Steinsson (2014) for recent contributions.
} 


\section{Theoretical framework}

We develop a simple economic geography model in which both private sector firms and a public sector employ workers. The model builds on Helpman (1998) and Redding and Sturm (2008). The main building blocks of the model are developed in this section and a more detailed exposition of the model is contained in Section A of the online technical appendix. In the model, monopolistically competitive private sector firms produce varieties of either a tradable or non-tradable good. Workers are mobile across locations and are in equilibrium indifferent across locations. The key novel feature of the model is the presence of a public sector that employs workers and produces a global public good. We treat the distribution of public sector jobs across locations as a policy parameter.

The key contribution of our model is that it highlights the different channels through which public and private employment interact in a spatial setting. It shows how public sector employment affects private sector employment through its impact on wages and house prices and also through potential productivity and amenity spillovers to the private sector. We use our reduced form evidence and a calibration of the model to shed light on the relative strength of these different mechanisms.

\subsection{Preferences and technology}

The economy consists of a number of locations, which we refer to as cities. The economy is populated by a mass of representative workers, $L$, who are mobile across cities and are endowed with a single unit of labor which is supplied inelastically with zero disutility in the city in which the worker resides. ${ }^{5}$ Utility is defined over a consumption index of tradable varieties, $C_{c}^{T}$, a consumption index of non-tradable varieties, $C_{c}^{N}$, consumption of housing, $C_{c}^{H}$, and the amenity level of the city, $B_{c} \cdot{ }^{6}$ The upper level utility function is assumed to be Cobb-Douglas:

$U_{c}=B_{c}\left(C_{c}^{T}\right)^{\mu}\left(C_{c}^{N}\right)^{\theta}\left(C_{c}^{H}\right)^{1-\mu-\theta}$

There are iceberg transport costs for tradable varieties between locations and for one unit of a variety produced in city $i$ to arrive in city $c$, a quantity $\tau_{i c}>1$ must be shipped. In contrast, non-tradable varieties can only be consumed in the city in which they have been produced.

The tradables consumption index takes the standard CES (DixitStiglitz) form. The dual tradables price index is as follows:

$P_{c}^{T}=\left[\sum_{i} n_{i}^{T}\left(p_{i}^{T} \tau_{i c}\right)^{1-\sigma}\right]^{1 /(1-\sigma)}$,

which uses the fact that all $n_{i}^{T}$ tradable varieties produced in city $i$ face the same elasticity of demand and charge the same equilibrium price $p_{i c}^{T}=\tau_{i c} p_{i}^{T}$ to consumers in city $c$. The price index implies that higher prices in cities $i$ or higher transport costs between cities $i$ and $c$ result in a higher tradables price index in city $c$. In contrast, non-tradable varieties can only be consumed in the city in which they are produced. Hence the non-tradable price index in city $c$ is:

$P_{c}^{N}=\left[n_{c}^{N}\left(p_{c}^{N}\right)^{1-\sigma}\right]^{1 /(1-\sigma)}=p_{c}^{N}\left(n_{c}^{N}\right)^{1 /(1-\sigma)}$,

which depends on the number of non-traded varieties produced in the city, $n_{c}^{N}$, and their equilibrium price, $p_{c}^{N}$, and where we have used the fact that all non-tradable varieties in a city charge the same equilibrium price.

Both tradable and non-tradable varieties are produced by monopolistically competitive firms using the same production technology. In

\footnotetext{
5 It would not be difficult to extend the model to also include non-working dependents for each worker.

${ }^{6}$ We use both $c$ and $i$ to index cities. When the distinction is important, we use $c$ to indicate a city when it is consuming and $i$ to indicate a city when it is producing.
}

particular, firms have a fixed cost in terms of labor of producing varieties, $F>0$, and a constant variable cost. The total amount of labor, $l$, required to produce $x$ units of a variety is:

$l=F+\frac{x}{\varphi_{i}}$,

where $\varphi_{i}$ captures the productivity of firms in city $i$. Firms maximize profits, ignoring their effect on the price index. ${ }^{7}$ This yields the standard result that the equilibrium free on board price of varieties is a constant mark-up over marginal cost:

$p_{i}=\left(\frac{\sigma}{\sigma-1}\right) \frac{w_{i}}{\varphi_{i}}$,

where $\sigma$ is the price elasticity of demand, which is the same for tradable and non-tradable varieties.

Instead of modeling a construction sector that provides housing we assume a simple housing supply function that relates house prices to the level of employment in a city:

$P_{c}^{H}=\left(L_{c}\right)^{\gamma}$,

where $\gamma$ is the elasticity of house prices with respect to employment in the city. ${ }^{8}$ We assume that expenditure on housing in city $c$, which is a constant share of city $c$ income, is redistributed to the residents of city $c$ through lump-sum transfers.

\subsection{Public sector}

The public sector produces a global public good (e.g. defense) that affects all agents in the economy equally independent of their location. Without loss of generality, we normalize the utility that agents derive from this public good to zero. We assume for simplicity that the total number of public sector workers in the economy is constant. The key policy decision is the distribution of public employment across cities where $L_{i}^{G}$ is the number of public sector workers in city $i .{ }^{9}$ Public sector workers in city $i$ are paid a wage $w_{i}^{G}$ that we assume to be equal to the wage $w_{i}$ that private sector workers in city $i$ receive. ${ }^{10}$ To finance public employment, the government levies a flat income tax $t$ on the wage income of both public and private sector workers to exactly satisfy the government budget constraint:

$t \sum_{i}\left(w_{i} L_{i}\right)=\sum_{i}\left(w_{i} L_{i}^{G}\right)$.

We assume that public sector employment in a city generates two potential spillovers to private sector workers in both the tradable and non-tradable sector in the same city. First, productivity of private sector workers in city $i$ is:

$\varphi_{i}=\xi_{i}\left(L_{i}^{G}\right)^{\alpha}$,

where $\xi_{i}$ captures sources of productivity other than public employment and $\alpha$ is the elasticity of the productivity of private sector firms in city $i$ with respect to the size of the public sector in this city. This general specification for productivity spillovers from public employment to the private sector captures a range of mechanisms. On the one hand, there could be classical knowledge spillovers with private sector firms being

\footnotetext{
${ }^{7}$ In line with the economic geography literature we assume that firms do not use land or housing as a factor of production. Adding housing to the production function of firms in our model would have the same effect as an increase in the share of expenditure on housing by consumers as the model assumes that workers have to live in the city in which they work.

${ }^{8}$ Saiz (2010) provides a micro-foundation for this housing supply function.

${ }^{9}$ In the model it is equivalent whether the public sector creates job openings in a particular city, or whether the public sector has a dedicated workforce that can be moved between cities.

${ }^{10}$ It would not be difficult to extend the model so that the public sector pays a higher wage than private sector firms and public sector employment is rationed in equilibrium. This would marginally change the quantitative implications of our model but not the qualitative insights.
} 
more productive because they learn, for example, about new policy initiatives. On the other hand, purchases of the public sector from local firms could boost local demand, which is observationally equivalent to a positive productivity shock.

Similarly, we assume that consumption amenities in city $i$ are determined by:

$B_{c}=\psi_{i}\left(L_{c}^{G}\right)^{\delta}$,

where $\psi_{i}$ captures determinants of amenities other than public employment and $\delta$ is the elasticity of city amenities with respect to the size of the public sector. ${ }^{11}$ Similar to productivity spillovers, our formulation of amenity spillovers could capture a number of different mechanisms. On the one hand, public sector workers could, for example, help to improve local schools or other local public goods. On the other hand, public sector workers might be able to divert a disproportionate share of national public spending to locations with larger concentrations of public employment.

\subsection{Spatial equilibrium}

We assume that workers are freely mobile across cities and arbitrage away all utility differences across cities in the long run. Substituting the equilibrium demand functions into the utility function (1), equal utility across cities implies:

$$
\frac{w_{c} B_{c}}{\left(P_{c}^{T}\right)^{\mu}\left(P_{c}^{N}\right)^{\theta}\left(P_{c}^{H}\right)^{1-\mu-\theta}}=k \quad \text { for all } c
$$

where we implicitly assume that all cities are populated in equilibrium. The intuition behind (10) is that higher wages or higher amenities make a city more attractive. At the same time higher housing costs or a higher price of tradable or non-tradable varieties make a city less attractive. In a spatial equilibrium, these opposing forces have to just offset each other so that utility is equalized across cities.

An alternative assumption to the free population mobility embodied in (10) would be to allow workers to have heterogeneous preferences across locations as in Redding (2016). In the presence of such heterogeneous location preferences, cities face an upward sloping labor supply curve rather than the perfectly elastic supply of labor implied by (10). As we study changes over four decades and federal ministries tend to recruit workers from across the country, we think that assuming perfect mobility of workers is a reasonable approximation and we return to the implications of relaxing this assumption in Section 2.4.

\subsection{Simulation}

We simulate the impact of changes in the location of public employment on the equilibrium distribution of private sector employment in a two-city version of our model. In particular we start with two exante identical cities and explore the impact of changes in the location of public employment across the two cities, holding the overall level of public sector employment in the economy constant. For this simulation we assume central values for the key parameters of the model. First, we assume an elasticity of substitution $(\sigma)$ of 5 which is similar to the values typically used in the international trade literature (see, for example, Feenstra (1994); Ghironi and Melitz (2005)). Second, we set the share of expenditure on housing in total expenditure $(1-\mu-\theta)$ to $1 / 3$, which is somewhat larger than the housing expenditure share of around 0.25 estimated by Davis and Ortalo-Magné (2011) for the US. Third, we set the share of public employment in total employment to

\footnotetext{
11 When we compare Bonn to its synthetic control it is plausible to assume that other determinants of productivity, $\xi_{i}$, and amenities, $\psi_{i}$ in equations (8) and (9) do not vary between Bonn and its synthetic control. We therefore assume that $\xi_{i}$ and $\psi_{i}$ are the same across cities when we simulate the model in Section 2.4 and undertake our quantitative analysis of the model in Section 7.5.
}

$12 \%$, which is the average level of pre-treatment public employment in Bonn and its synthetic control. This is also not far from the 2005 OECD average reported in OECD (2009), as discussed in the introduction. Fourth, we set the share of expenditure on both tradable output $(\mu)$ and non-tradable output $(\theta$ ) equal to $1 / 3$. Moretti (2010)and Faggio and Overman (2014) assume that only manufacturing is tradable, but this ignores that some services are also tradable. In contrast, Lombardo and Ravenna (2012) estimate the share of tradable sectors at the level of countries and report tradable shares in excess of $50 \%$ of employment. Fifth, we assume that the iceberg trade cost for tradable output between the two cities $\left(\tau_{i c}\right)$ is equal to 1.25 , which is very similar to the average transport costs (excluding border-related costs and wholesale distribution costs) of $21 \%$ of the value of goods estimated by Anderson and van Wincoop (2004). Finally, Saiz (2010)estimates a population-weighted average elasticity of housing supply in US metropolitan areas of 1.75. We are interested in the inverse of this, i.e. the elasticity of house prices with respect to population or employment in a city $(\gamma)$, which we set to $1 / 1.75=0.57 .{ }^{12}$

Fig. 1 shows the simulation results of a shift in public employment from city 2 to city 1 for different assumed values of the amenity and productivity spillover parameters $\delta$ and $\alpha$. The figure has a number of striking features. First, the figure shows that the impact of shifting public sector employment from city 2 to city 1 on private sector employment depends clearly on the magnitude of the productivity and amenity spillovers in the model. With large spillovers, private sector employment in city 1 across the tradable and non-tradable sector substantially increases in response to this reallocation of public sector employment. In contrast, in the absence of spillovers ( $\alpha=0$ and $\delta=0$ ), private sector employment in city 1 declines so much that total employment in city 1 actually falls. Second, if the population of city 1 increases in response to a shift in public employment to this city, then we see increases in both wages and house prices in city 1 relative to city 2 . However, the increase in house prices is quantitatively much more pronounced than the increase in nominal wages.

To see the intuition behind these patterns, it is best to break up the adjustment to a new long-run equilibrium into a short-run adjustment, before workers can relocate across cities, and a long-run adjustment when workers can move across cities in response to real wage differences. In the short-run, additional demand for labor from the public sector in city 1 has to be met by a reduction in employment in the private sector of city 1 . As consumers spend a constant share of their income on non-tradable goods, this reduction in private sector employment will in the short-run come entirely from the tradable sector, whose output can be imported from the other city, while non-tradable goods by definition have to be produced locally.

In the short-run, housing prices in city 1 and city 2 , which are a function of the level of population in a city, are unchanged. However, the increase in public employment and reduction in tradable sector employment in city 1 relative to city 2 affect both nominal and real wages through several channels. First, as more tradable varieties are now imported from city 2 to city 1 at positive transport costs, the price index for tradable goods increases in city 1 , which reduces real wages and hence utility in city 1 . Second, this increase in the price of tradables softens the degree of competition in city 1 , which increases the nominal wage that tradable sector firms in city 1 can pay in a zero-profit equilibrium. ${ }^{13}$ Third, positive productivity spillovers to the private sector from the higher level of public employment in city 1 directly increase nominal wages in city 1 as private sector firms can now pay higher wages in a zero-profit equilibrium. Finally, positive amenity spillovers to the pri-

\footnotetext{
12 We also normalize the fixed costs $F$ to one, which simply rescales the number of varieties and hence real wages across both cities.

${ }^{13}$ Higher wages in the tradable sector of a city also increase wages in the non-tradable sector and public sector of the city due to the assumption of an integrated labor market in each city.
} 


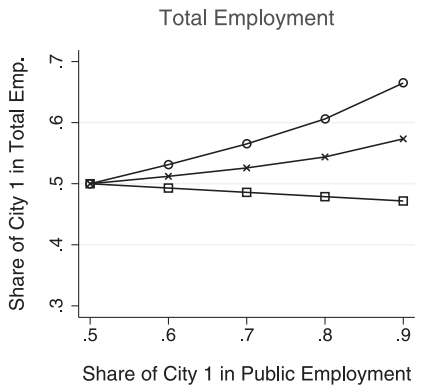

Private Non-Tradable Employment

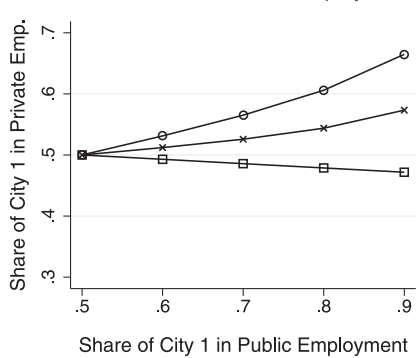

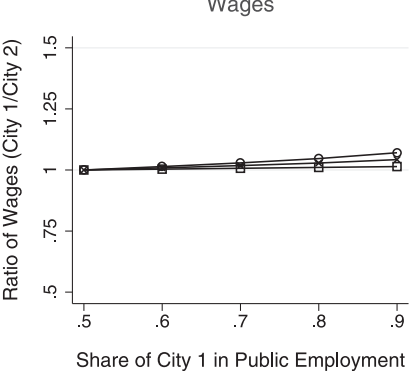

Private Tradable Employment
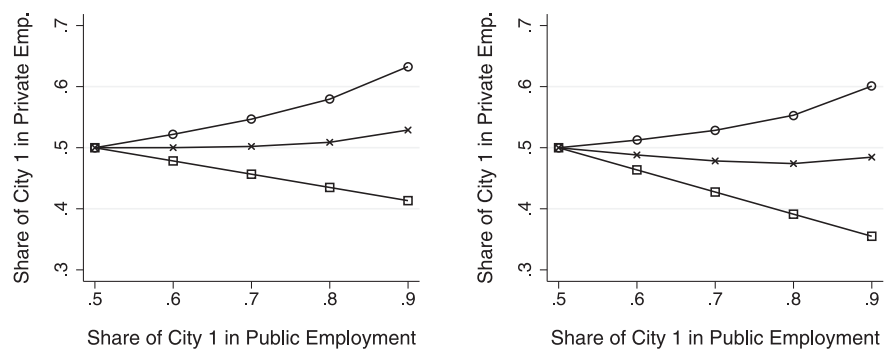

Share of City 1 in Public Employment

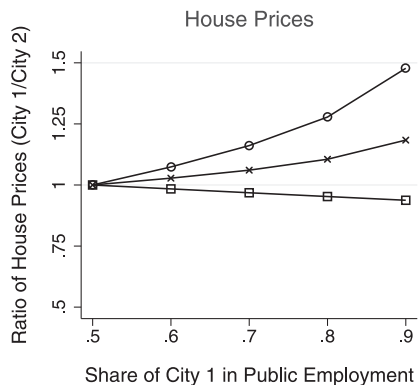

$$
\longrightarrow \text { Large Spillovers } \longrightarrow \text { Intermediate Spillovers } \quad \square \text { No Spillovers }
$$

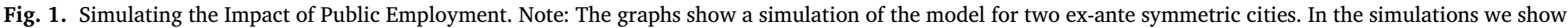
three scenarios. (i) no spillovers; (ii) intermediate spillovers with $\alpha=\delta=0.004$ and (iii) higher spillovers with $\alpha=\delta=0.008$.

vate sector from the higher level of public employment in city 1 do not change nominal wages in the short-run, but increase the relative utility of living in city 1 relative to city $2 .^{14}$

In the long-run, workers are mobile across cities and will respond to the utility differences that have opened up during the short-run adjustment by migrating between cities. With either the intermediate or high level of productivity and amenity spillovers from public employment to the private sector considered in Fig. 1, real wages and utility are higher in city 1 relative to city 2 after the short-run adjustment to a shift in public employment from city 2 to city 1 . This triggers an inflow of workers to city 1 that results in an expansion of production in both the tradable and non-tradable sectors of city 1 . This inflow of workers increases house prices in city 1 relative to city $2 .{ }^{15}$ How much house prices have to increase to reach a new long-run equilibrium in which utility is again equalized across cities depends on the degree of worker mobility. If there are large barriers to labor mobility across cities, then a small increase in house prices is sufficient to end migration to city 1 and restore utility equalization. If there are instead no barriers to labor mobility, which is our baseline assumption, then the city with higher real wages after the short-run adjustment experiences a larger inflow of workers and a larger resulting increase in house prices until spatial equilibrium is re-established. To what extent higher wages or higher house

\footnotetext{
${ }^{14}$ In line with the wider economic geography literature, our model exhibits constant returns to scale at the level of the sector despite the increasing returns to scale at the level of each firm. In a model where the private sector has decreasing returns to scale, due to a fixed factor of production in each city for example, a reduction in private sector employment in a city would increase wages in the city also due to the increase in the marginal product of labor at this smaller scale of production in the private sector.

15 This increase in the size of city 1 relative to city 2 also has further general equilibrium impacts on wages across the two cities. The larger city benefits from better market access due to consumers being able to buy from its firms without having to pay the transport costs, which further increases wages that firms in the larger city can pay in a zero-profit equilibrium.
}

prices therefore act as the dispersion force is a function of the degree of labor mobility, where higher labor mobility results in a larger increase in house prices relative to wages.

In the special case where an increase in public employment has neither an impact on private sector productivity nor amenities, our model predicts that private sector employment in city 1 actually falls so much in response to an increase in public sector employment that total employment in city 1 declines. This more than proportional reduction in private sector employment in the absence of productivity or amenity spillovers would become a one to one reduction in private employment, if there were no trade costs across cities. ${ }^{16}$ As discussed above, in the absence of productivity or amenity spillovers, an inflow of public sector jobs has two opposing effects in the short-run. First, less local production of tradable varieties in city 1 implies that more varieties have to be imported from city 2 at positive trade costs. Second, this reduction in local competition in the tradable sector increases output prices and hence wages across all workers in city 1 . This second effect is dominated by the first effect so that real wages in city 1 decline in the short-run, which in turn triggers a population outflow until house prices in city 1 have fallen sufficiently to re-establish spatial equilibrium.

We have also simulated the model for the case of only productivity spillovers or only amenity spillovers. Both types of spillovers have a qualitatively similar effects. Sufficiently strong spillovers of either type in response to increased public employment in city 1 increase private sector employment in the tradable and non-tradable sector of city 1 . However, amenity spillovers have a larger positive effect on house prices than wages, relative to the impact of productivity spillovers on house prices and wages. This prediction of the model is similar in spirit to the classic Rosen (1979) and Roback (1982) analysis.

In summary, the model illustrates how public sector employment affects private sector employment through its impact on wages and house

\footnotetext{
16 See Redding and Sturm (2008) and Handbury and Weinstein (2015) for recent evidence for the presence of trade costs also for trade across cities.
} 
prices and also through potential amenity and productivity spillovers to the private sector. The relative strength of these mechanisms is an open empirical question to which we now turn. In Section 7.5 we return to the theoretical model and determine for which parameter values it best fits the reduced form evidence.

\section{Historical background}

In the wake of the Second World War, Germany was divided into four different parts: East Germany, West Germany, areas that became part of Poland, and an area that became part of the Soviet Union. Berlin, the pre-war capital of Germany, was situated approximately $200 \mathrm{~km}$ to the east of the border between East and West Germany. Berlin was jointly occupied by U.S., British, French, and Soviet troops and divided into four sectors of occupation. The origins of Germany's division can be traced back to a wartime protocol that organized Germany into zones for the purposes of the post-war military occupation. With the intensification of the Cold War, cooperation between the Western allies and the Soviet Union deteriorated and West Germany was founded in 1949 on the area of the U.S., British, and French zones, while East Germany was founded in the same year on the Soviet zone (see, for example, Franklin (1963) and Kettenacker (1989)).

As part of the foundation of West Germany, a location for the new West German government had to be found. There were four main contenders for the seat of government, which in order of their 1939 population were Frankfurt, Stuttgart, Kassel and Bonn. It was widely believed that Frankfurt was the obvious choice for several reasons: It had been the seat of the first German parliament in 1848; it was the largest of the candidate cities; and it was centrally located in West Germany with good transport links. However, on 10 May 1949, the West German Parliamentary Council ("Parlamentarische Rat") voted narrowly for Bonn as the new capital of West Germany. Of the 65 delegates, 29 voted for Frankfurt and 33 for Bonn, with one invalid vote and two abstentions. This decision was confirmed by the newly constituted West German parliament on 3 November 1949 with 200 votes for Bonn versus 176 for Frankfurt (Floehr (1986)). ${ }^{17}$ A popular myth is that Konrad Adenauer, Germany's first post-war chancellor, single-handedly engineered this outcome, as he was of an advanced age and lived on the outskirts of Bonn. ${ }^{18}$ The truth is likely more mundane. The heavy military presence of American troops in Frankfurt was viewed as a disadvantage for an independent West German government. ${ }^{19}$ Moreover, making Bonn the capital of West Germany was viewed as a signal that the division of Germany was a temporary arrangement that had to be overcome as soon as possible. While the new West German government had its first parliamentary session already in September 1949, the establishment of a new federal government in Bonn was a long drawn out process, requiring the construction of new buildings and recruitment of thousands of new civil servants. ${ }^{20}$

\footnotetext{
17 The unexpected choice of a provincial town as Germany's capital was widely ridiculed. The New York Herald Tribune called Bonn in 1959 "one of the strangest capitals of the twentieth century"; the English envoys referred to the British Embassy in Bonn as "Her Majesty's only mission in a cornfield" and a Newsweek correspondent was surprised to see that his news bureau close to the federal parliament "faced a meadow on which a shepherd grazed his flock every Friday afternoon" (as cited in Wise (1998)).

18 A common German joke at the time was that "If you say 'A' for Adenauer you also have to say 'B' for Bonn".

19 Adenauer (1965) argues that this point was critical in swinging the vote in favor of Bonn.

${ }^{20}$ While there is no reliable data on where the newly recruited civil servants in Bonn came from, the West German government was keen to establish a new democratic administration that excluded people who were connected to the ruling NSDAP party during Nazi Germany. While this was not always successful, as a number of post-war scandals revealed, the establishment of Bonn is best interpreted as the step by step setting up of a new administration rather than the wholesale relocation of government employees from Berlin to Bonn.
}

Despite hopes in the immediate post-war period that division would be short-lived, it was over time formalized in international treaties and became widely believed to be permanent. West German opinion polls in the 1980s show that less than $10 \%$ of the respondents expected a reunification to occur during their lifetime (Herdegen (1992)). However, increasing dissatisfaction among East Germans led to large-scale demonstrations in 1989 and culminated in the fall of the Berlin Wall on 9 November 1989. Only eleven months later, on 3 October 1990, East and West Germany were formally reunified. On 20 June 1991 the German parliament voted narrowly by 338 to 320 to relocate the parliament and parts of the federal ministries from Bonn to Berlin. Bonn was generously compensated for this loss of status and economic power. This involved financial compensation, the allocation of new institutions of national and international significance, and the agreement that every federal ministry would have offices both in Berlin and Bonn and the majority of federal government employment would remain in Bonn. After extensive building works, the German parliament and parts of each federal ministry moved from Bonn to Berlin in September 1999. ${ }^{21}$

\section{Data}

Our basic dataset is panel data on employment in Bonn and a set of 40 control cities which were also located in West Germany. The control cities are the 20 West German cities with a 1939 population just above Bonn and the 20 cities with a 1939 population just below Bonn. ${ }^{22}$ Bonn itself had 152,057 inhabitants in 1939 and was the 31st largest West German city in 1939. The population of the 40 control cities ranges from 83,385 in Bottrop to 458,429 in Stuttgart in 1939. We have also experimented with using a larger number of control cities but this has no meaningful impact on the results. Fig. 2 shows the spatial distribution of Bonn and the 40 control cities. The dataset contains observations from the pre-war censuses in 1925, 1933 and 1939 as well as data from the post-war censuses in 1946, 1950, 1961, 1970 and 1987. To make cities as comparable as possible over time, we follow Redding and Sturm (2008) and aggregate settlements that had at least 10,000 inhabitants in 1919 and merged with one of our cities during the sample period in all years in the data. A list of all aggregations is contained in Section C.7 of the online technical appendix.

Due to Germany's federal structure in the post-war period, census employment data at the city level is published by the statistical offices of the different West German states ("Länder") while the pre-war data was published by the Statistical Office of Germany ("Statistisches Reichsamt"). We are able to disaggregate total employment into 10 sectors ("Wirtschaftsabteilungen"). These 10 sectors have been used unchanged in the 1961, 1970 and 1987 censuses. We use a concordance to aggregate the employment data from the 1950 and 1946 censuses to the same 10 sectors. The 1933 and 1925 censuses have also published employment data at the city level for a large number of sectors. We have developed a concordance to aggregate this data to the same 10 sectors that are used in the post-war data. The 1939 census has only published employment at the city level in four sectors which are aggregates of the 10 sectors. We use the 1933 employment shares in each city to disaggregate employment in 1939 in these

\footnotetext{
21 The extensive compensation and limited relocation of federal ministries suggest that this was a much smaller shock for Bonn. Consistent with this there is no evidence for a change in the growth rate of population or employment in Bonn in the years after 1999. We therefore concentrate on the much larger and cleaner shock of the arrival of the federal government in Bonn in the wake of the Second World War.

${ }^{22}$ We exclude the city of Saarbrücken from the control group, because Saarbrücken was under the rule of the League of Nations from 1919 to 1935 and under French rule from 1945 to 1957.
} 


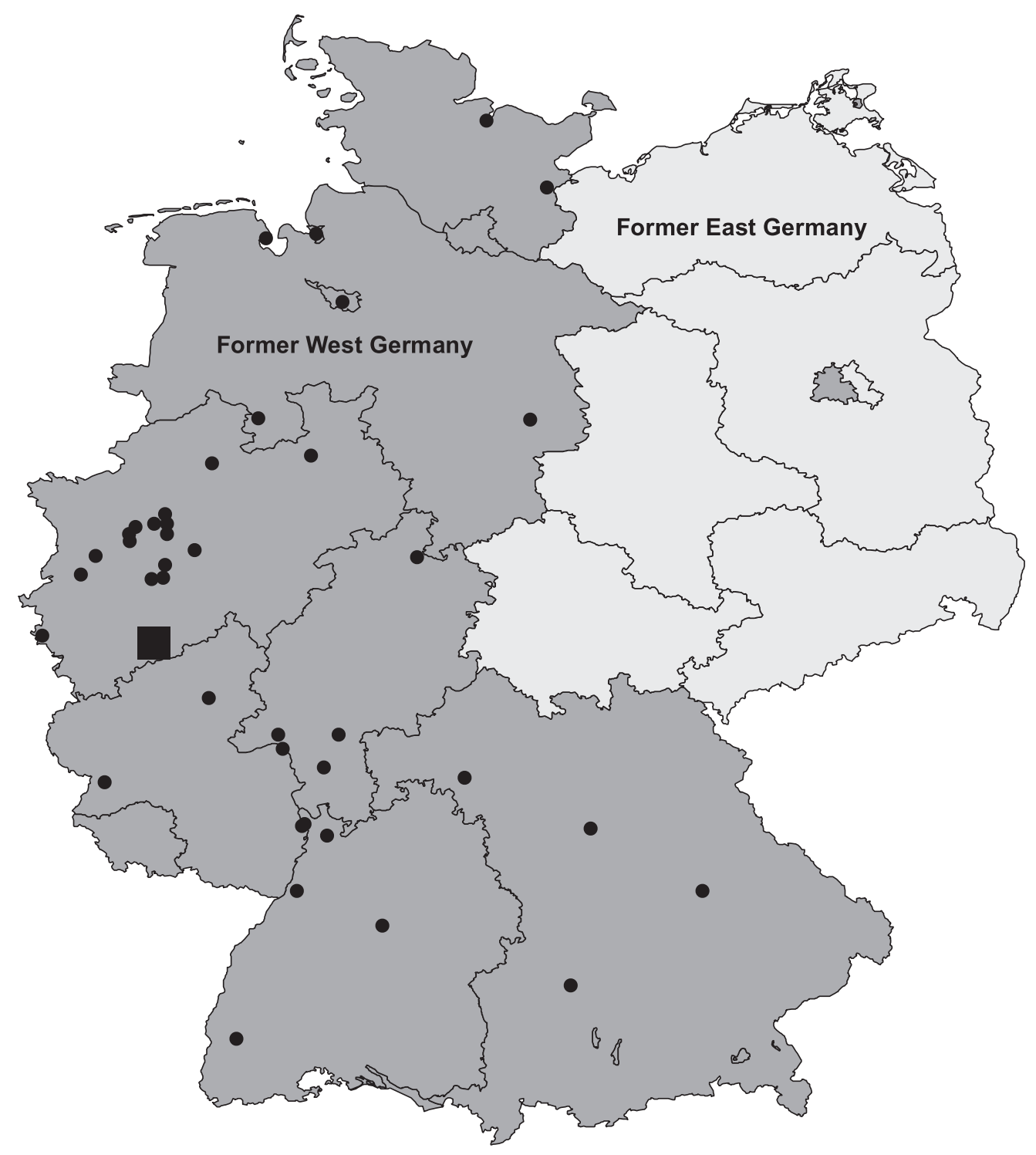

Fig. 2. Bonn and the Control Cities. Note: The map shows the location of the city of Bonn (square) and the 40 control cities that comprise the control group in the difference-in-differences comparisons and the donor pool for the synthetic control approach.

four sectors into the same 10 sectors that we use for other years. ${ }^{23}$ Dropping the 1939 data from the sample makes no difference to our results. $^{24}$

The 10 sectors into which we are able to disaggregate employment (and their 1987 German name) are agriculture ("Land- und Forstwirtschaft und Fischerei"), mining and energy ("Energie- und Wasserversorgung und Bergbau"), construction ("Baugewerbe"), industry ("Verarbeitendes Gewerbe"), trade ("Handel"), transport and communication ("Verkehr und Nachrichtenübermittlung"), finance and insurance ("Kreditinstitute und Versicherungsgewerbe"), other services ("Dienstleistungen von Unternehmen und freien Berufen"), non-profit sector ("Organisationen ohne Erwerbszweck und private Haushalte"), public sector ("Gebietskörperschaften und Sozialversicherung"). Agricultural employment is very low in our sample of cities and we omit

\footnotetext{
${ }^{23}$ Sections C. 1 to C.6 of the online technical appendix provide detailed information on the sources for each year of our data and the concordance of sectors across years.

${ }^{24}$ We also use a similar imputation to disaggregate employment reported in 4 sectors into 10 sectors for a small number of additional observations due to missing 10 sector employment breakdowns for smaller cities.
}

it when we disaggregate total employment into its sectors. Public employment in the 1961 to 1987 censuses consists of a narrow definition of public employment that only includes employment in the public administration and social security administration. It does not include employment in the health sector and education, which are both part of the sector "other services", and also does not include employment in state-owned enterprises. Across Bonn and the control cities the average share of public employment in total employment in our data is just over $12 \%$ in 1987 , which is not far from the 2005 OECD average discussed in the introduction. ${ }^{25}$

\footnotetext{
${ }^{25}$ As discussed in detail in Section C of the online technical appendix, data limitations in the earlier years of our long time series imply that the definition of public employment changes slightly over time. In particular, in the pre-war censuses of 1925, 1933 and 1939 public employment includes the military and the clergy and in 1950 it includes employment by the occupying forces and foreign embassies. These changes in the definition of public employment obviously affect all cities in our sample and any differential change in public employment caused by these changes in definition should be small compared to the large increase in public employment in Bonn due to the establishment of the West German government in Bonn.
} 
In addition to the employment data, we have collected a number of datasets to provide evidence for the mechanisms emphasized by our model. First, we use data reported in Deutscher Städtetag (1988), which contains a number of proxies for consumption amenities across the cities in our sample in 1987. We have also obtained similar data for 1929/1930 for a much smaller number of proxies for amenities from Deutscher Städtetag (1931). Second, we have collected data on gross value added per worker in Bonn and the control cities from Gemeinschaftsveröffentlichung der Statistischen Landesämter (1991). Third, we use data from the Historic Employment and Establishment Statistics (HES) database (see Bender et al. (2000) for a detailed description) for 1987 that allows us to estimate individual-level wage regressions. While comparable wage data does not exist for the pre-war period, we proxy pre-war wage differences across cities with information on payroll tax receipts in 1937 reported in Statistisches Reichsamt (1941). Third, we have obtained data for 1986 to 1988 on the average price of different types of real estate across a sample of West German cities from the Association of Real Estate Agents ("Ring Deutscher Makler RDM"). ${ }^{26}$ Finally, we use data reported in Deutscher Städtetag (1986) on the number of hotel nights per capita in 1985 for all cities in our sample.

\section{Empirical approach}

Our basic empirical approach is a simple difference-in-differences comparison of Bonn and our 40 control cities:

$Y_{c t}=\gamma+T_{c}+T_{c} \times D_{t}+\lambda_{t}+\varepsilon_{c t}$

where $Y_{c t}$ is employment in city $c$ in period $t$ and employment can be total employment or employment in sub-sectors depending on the specification; $T_{c}$ is a dummy that is equal to one for Bonn and zero otherwise; $D_{t}$ is a dummy that is equal to one after 1949 and zero otherwise; $\lambda_{t}$ is a full set of time dummies; $\varepsilon_{c t}$ is an error term. As we observe Bonn and the control group of cities for several periods prior to treatment, we can assess whether the treatment city and control group of cities move in parallel before the treatment. Whereas difference-in-differences comparisons are one of the classic approaches to analyze natural experiments, there are two potential concerns with this approach in our setting. First, as we only have one treatment unit (Bonn), it is particularly important to compare this city to a control group that is as similar as possible to Bonn. Second, Conley and Taber (2011) point out that clustering standard errors at the level of cities is likely to underestimate standard errors if there is only one treatment unit in a difference-in-differences regression.

To address both of these concerns, we also construct a synthetic control city for Bonn as proposed by Abadie and Gardeazabal (2003) and extended by Abadie et al. (2010). The main idea of the synthetic control method (SCM) is to acknowledge that a simple average of other cities may not be a good enough control, and instead to let the data speak and search for a weighted average of cities that best mimics the pre-treatment trend (predictors) in Bonn. More formally, let $J$ be the number of available control cities ('donor pool'), where $J$ is equal to 40 in our application. Let $W=\left(w_{1}, \ldots, w_{J}\right)^{\prime}$ be a $(J \times 1)$ vector of nonnegative weights that sum to one. The scalar $w_{j}$ represents the weight of city $j$ in the synthetic Bonn. The synthetic control method chooses the weights $W$ so that the synthetic Bonn most closely resembles the actual one before 1949 .

To understand how the weights are determined, let $X_{1}$ be a $(K \times 1)$ vector of pre-1949 values of $K$ employment predictors for Bonn. Similar to $X_{1}, X_{0}$ is defined as a $(K \times J)$ matrix that contains the values of the same employment predictors for the $J$ possible control cities. We include in $X_{1}$ and $X_{0}$ both pre-treatment values of employment and exogenous covariates. In particular we include in all specifications the pre-treatment values of employment in the non-tradable sector, the trad-

\footnotetext{
${ }^{26}$ We thank Martin Wersing for sharing the data.
}

able sector and the public sector. ${ }^{27}$ These employment variables capture differences in sectoral employment patterns that may affect the posttreatment trend. As exogenous covariates that could influence post-war employment growth we include a dummy for proximity $(75 \mathrm{~km})$ to the border between East and West Germany to control for market access changes as in Redding and Sturm (2008) and two measures of warrelated destruction reported in Kästner (1949): the amount of rubble in cubic meters per capita and the percentage of the 1939 housing stock that has been destroyed.

Let $V$ be a diagonal matrix with non-negative components. The values of the diagonal elements of $V$ reflect the relative importance of the $K$ employment predictors in the construction of the synthetic control. The vector of weights $W$ is chosen to minimize the objective function:

$\left(X_{1}-X_{0} W\right)^{\prime} V\left(X_{1}-X_{0} W\right) \quad$ subject to $\quad w_{j} \geq 0$.

The optimal weights $W^{*}$ that minimize this objective function clearly depend on the choice of weighting matrix $V$. We follow Gobillon and Magnac (2016)and set $V$ to be the identity matrix, which gives equal weights to all predictor variables. Furthermore, we standardize all predictor variables to avoid the pitfall that differences in the units of measurement determine the relative weight of predictor variables. ${ }^{28}$ Alternatively, Abadie and Gardeazabal (2003) and Abadie et al. (2010) propose a data-driven procedure to choose $V$ such that employment before 1949 is best reproduced by the synthetic control defined by $W^{*}(V)$, i.e. the root mean square prediction error (RMSPE) is minimized over the pre-treatment period. We have also estimated this alternative specification and find very similar results with this approach and our results are therefore not sensitive to the choice weighting matrix $V .{ }^{29}$

The treatment effects $\alpha_{1 t}$ for Bonn in the post-treatment years $t=$ 1950, 1961, 1970, 1987 are then estimated as the difference between Bonn and the synthetic control city:

$\hat{\alpha}_{1 t}=Y_{1 t}-Y_{0 t} W^{*}$

where $Y_{1 t}$ is the outcome for Bonn in year $t$ and $Y_{0 t}$ is a (row) vector with the same outcome for the $J$ control cities in year $t$. Since we use employment in the tradable, non-tradable and public sector as our predictor variables no matter whether the outcome variable is total employment or employment in one of our sub-sectors, the weights $W^{*}$ do not change across outcomes. This is our preferred specification as it ensures that the cities that make up the synthetic control for Bonn are the same across specifications. This also implies that the estimated treatment effects for the different sub-sectors add up to the estimated treatment effect for total employment. ${ }^{30}$

\section{Basic results}

In this section, we use both difference-in-differences and the synthetic control method to establish a counterfactual for Bonn in the absence of the arrival of the federal government. We begin by looking at

\footnotetext{
${ }^{27}$ We discuss in Section 6 below how we define employment in the tradable and non-tradable sector.

${ }^{28}$ The standardization of the predictor variables is automatically carried out in the current implementation of synthetic controls in STATA.

${ }^{29} \mathrm{Kaul}$ et al. (2017)argue that using all outcome lags as separate predictors renders the other covariates irrelevant. This concern does not apply to our procedure since using the identity matrix for $V$ assigns equal weights to all covariates.

${ }^{30}$ Figures B.1 to B.4 of the online technical appendix show results of specifications where we do not hold the weights $W^{*}$ constant across different subsectors, but use the pre-treatment values of the respective measure of employment as predictor variables (along with our exogenous covariates). Doing so results in different weights $W^{*}$ across specifications with different measures of employment as the dependent variable. Reassuringly, these alternative specifications lead to very similar results even though the treatment effects estimated for sub-sectors do not exactly add up to the estimated treatment effect for total employment.
} 
Table 1

Balancing Tests.

\begin{tabular}{|c|c|c|c|c|c|}
\hline & \multirow[t]{2}{*}{ (1) } & (2) & (3) & & (5) \\
\hline & & \multicolumn{2}{|l|}{$\mathrm{DiD}$} & \multicolumn{2}{|c|}{ Synthetic Control } \\
\hline & Bonn & Control & B-C & Control & B-C \\
\hline Non-tradable empl. in 1925 (in 1000s) & 30.910 & 35.885 & -4.975 & 29.194 & 1.716 \\
\hline Non-tradable empl. in 1933 (in 1000s) & 33.854 & 40.578 & -6.724 & 35.617 & -1.763 \\
\hline Non-tradable empl. in 1939 (in 1000s) & 36.424 & 43.978 & -7.554 & 39.645 & -3.221 \\
\hline Non-tradable empl. in 1946 (in 1000s) & 30.111 & 33.317 & -3.206 & 28.618 & 1.493 \\
\hline Tradable empl. in 1925 (in 1000s) & 20.502 & 30.084 & -9.582 & 18.965 & 1.537 \\
\hline Tradable empl. in 1933 (in 1000s) & 20.375 & 30.287 & -9.912 & 20.529 & -0.154 \\
\hline Tradable empl. in 1939 (in 1000s) & 21.927 & 34.298 & -12.371 & 22.055 & -0.128 \\
\hline Tradable empl. in 1946 (in 1000s) & 20.621 & 30.680 & -10.059 & 22.321 & -1.700 \\
\hline Public empl. in 1925 (in 1000s) & 4.840 & 5.407 & -0.567 & 5.509 & -0.669 \\
\hline Public empl. in 1933 (in 1000s) & 7.000 & 6.060 & 0.940 & 6.165 & 0.835 \\
\hline Public empl. in 1939 (in 1000s) & 6.932 & 6.588 & 0.344 & 7.013 & -0.081 \\
\hline Public empl. in 1946 (in 1000s) & 10.929 & 7.361 & 3.568 & 10.523 & 0.406 \\
\hline Border Dummy (within 75km) & 0.000 & 0.125 & -0.125 & 0.002 & -0.002 \\
\hline Rubble (in cubic meters per capita) & 7.300 & 12.240 & -4.940 & 7.611 & -0.311 \\
\hline Destroyed Housing (as \% of 1939 stock) & 37.300 & 39.950 & -2.650 & 36.388 & 0.912 \\
\hline
\end{tabular}

Notes: The table shows the balance of a set of predictor variables between Bonn and (i) the unweighted average of the 40 control cities (columns 2 and 3) and (ii) the synthetic control group (columns 4 and 5). These predictor variables are used to determine the synthetic control group and they include the level of non-tradable employment, tradable employment and public employment in all four pre-treatment years, a dummy for locations in proximity (within $75 \mathrm{~km}$ ) to the German-German border and two measures of Second World War destruction (rubble and destroyed housing stock).

three outcomes: total employment, public sector employment and private sector employment. We then further disaggregate private sector employment into its sub-sectors to examine the heterogeneity of the impact of increases in public employment on different parts of the private sector.

\subsection{The development of public, private and total employment}

Fig. 3 shows our basic results for the impact of the arrival of the federal government in Bonn on public employment, private employment and total employment. The three panels on the left-hand side of the figure compare Bonn (solid line) to the average of the 40 control cities (dashed line) in a difference-in-differences comparison while the three panels of the right-hand side compare Bonn to its synthetic control. The synthetic Bonn is a weighted average of the cities of Heidelberg (16.8\%), Kiel (0.2\%), Koblenz (34.6\%), Mannheim (4.7\%), Münster $(8.1 \%)$, Stuttgart $(7.0 \%)$, Wiesbaden $(25.4 \%)$, and Wilhelmshaven $(3.2 \%){ }^{31}$ Table 1 compares the similarity between Bonn and both the unweighted average of the 40 control cities and the synthetic Bonn before the treatment. The table shows that across the predictor variables, i.e. the pre-treatment values of non-tradable employment, tradable employment and public employment as well as our exogenous growth predictors, Bonn is more similar to the synthetic Bonn than the average of the 40 control cities.

The closer fit between Bonn and its synthetic control compared to the average of the 40 control cities is also visible in Fig. 3. Even though we use the same weights to compute the synthetic control for total, public and private employment in Bonn, we find that Bonn and its synthetic control track each other very closely both in terms of levels and growth rates before Bonn becomes the capital of West Germany in 1949. In contrast, Bonn and the average of the 40 control cities are not as close to each other, particularly for private sector and total employment. Bonn has less private sector employment than the average of the 40 control cities and the treatment and control group also have slightly different growth rates. The same difference between Bonn and the average of the

31 As noted before, we will use these weights for all subsequent sub-sector specifications such as, for example, public sector and private sector employment.
40 control cities is also visible in total employment in years prior to the arrival of the federal government.

Comparing Bonn to either the average of the 40 control cities or the synthetic Bonn after 1949 reveals a number of striking patterns. First, public employment in Bonn increases substantially relative to either counterfactual over the post-war period. While the new West German parliament already met for the first time in Bonn in the fall of 1949 there is not yet any visible increase in public employment in Bonn in the 1950 census. However, over the next two decades public employment in Bonn steadily increases relative to the counterfactual, consistent with the view that setting up a new federal government is a long drawn-out process. Comparing the change in public sector employment in Bonn between 1987 and the pre-treatment years to the same change in the synthetic control we find a treatment effect on public sector employment in Bonn of just over 15,600. ${ }^{32}$ When we compare the change in public employment in Bonn to the change in public employment in the unweighted average of the 40 control cities, we find a marginally larger treatment effect on public employment. Second, this rapid expansion of public employment is not mirrored in an equally rapid expansion of private employment in Bonn. Comparing the change in private sector employment in Bonn to the same change in the synthetic control we find a treatment effect on private sector employment in Bonn of just under 13,400 private sector workers. Comparing Bonn to the unweighted average of the 40 control cities instead results in a larger treatment effect of just over 21,600 private sector workers, but this estimate seems less reliable due to the much poorer fit between Bonn and the average of the 40 control cities during the pre-treatment years in terms of private sector employment. Third, as total employment is the sum of public and private employment, total employment also rises rapidly in Bonn relative to either counterfactual. The relative increase in public employment in Bonn is reflected in the development of the percentage share of public employment in total employment in Bonn, which increases from an aver-

\footnotetext{
32 This treatment effect is computed as the change in public sector employment in Bonn between the average of the pre-treatment observations (1925, 1933, 1939 and 1946) and 1987 of 21,428 compared with the analogous change in the synthetic control for Bonn of 5,791 which results in a treatment effect of $21,428-5,791=15,637$. Other treatment effects in this section are similarly computed.
} 
Total employment (Diff-in-diff)

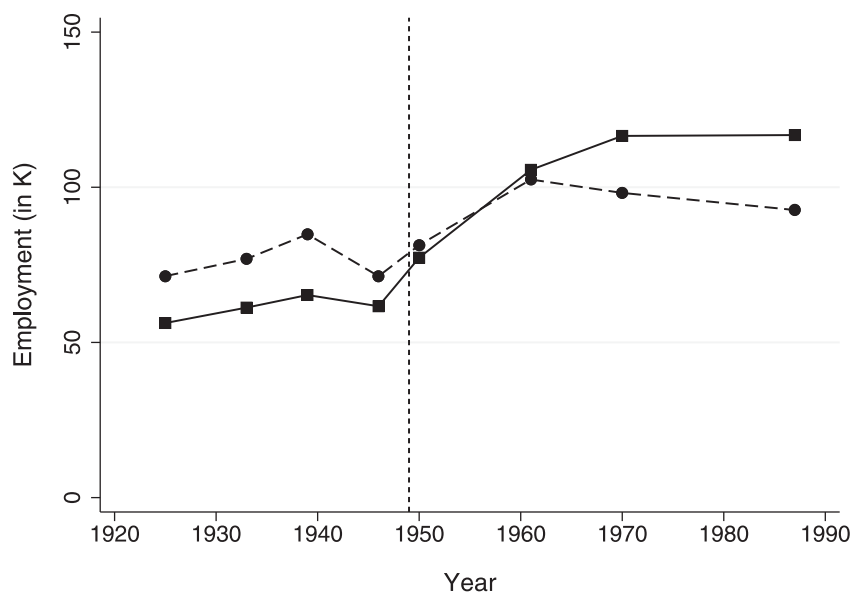

Public sector employment (Diff-in-diff)

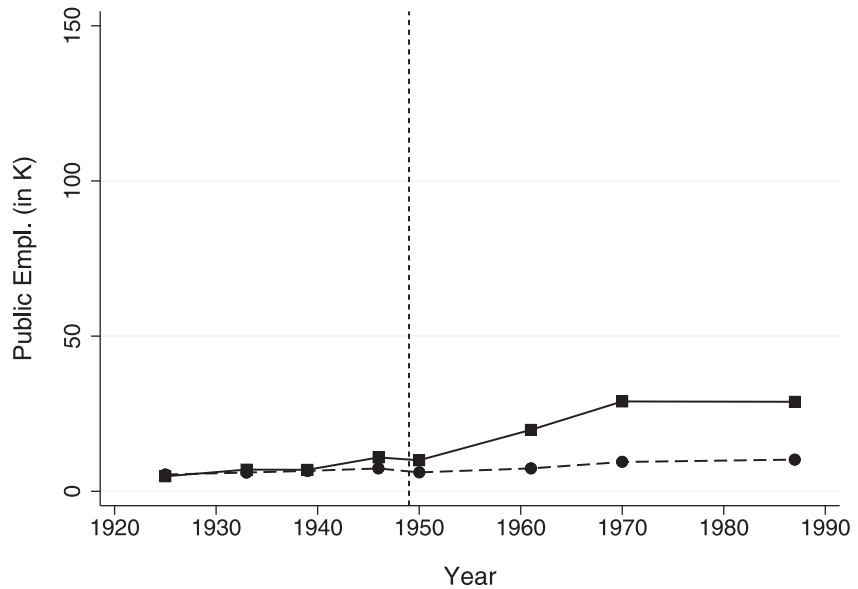

Pricate sector employment (Diff-in-diff)

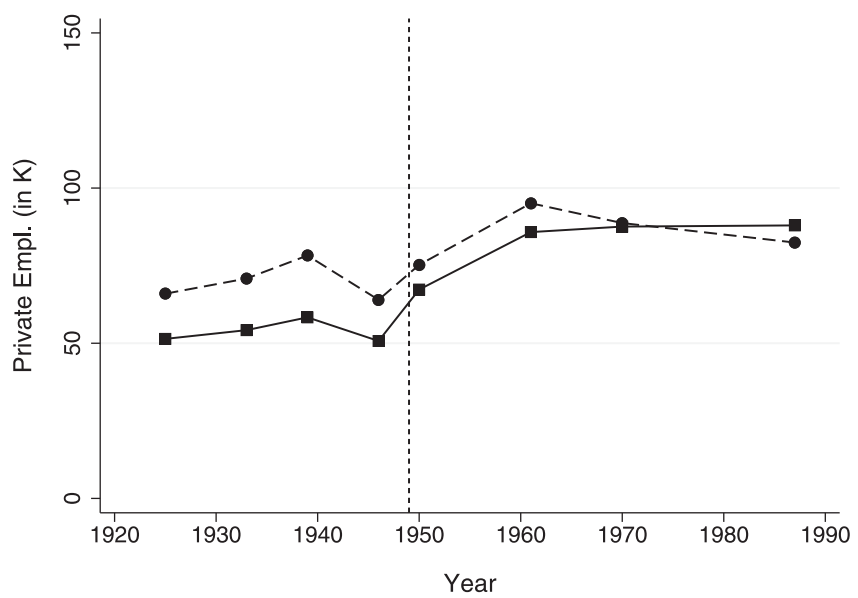

\section{Total employment (Synthetic control)}

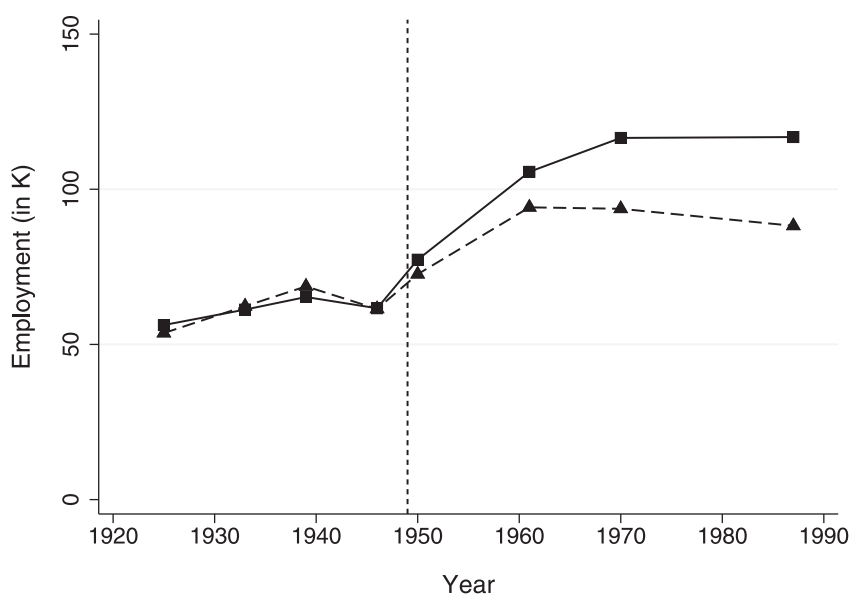

Public sectoremployment (Synthetic control)

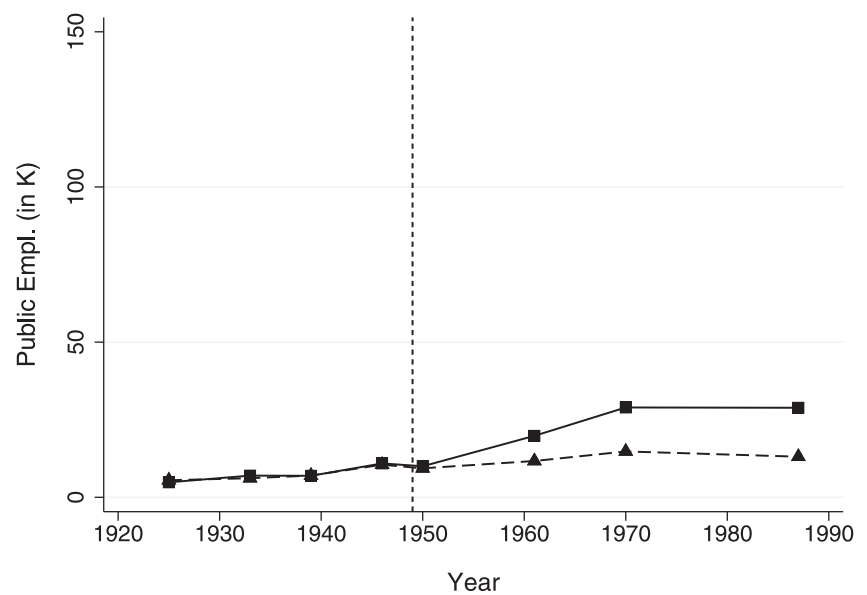

Private sectoremployment (Synthetic control)

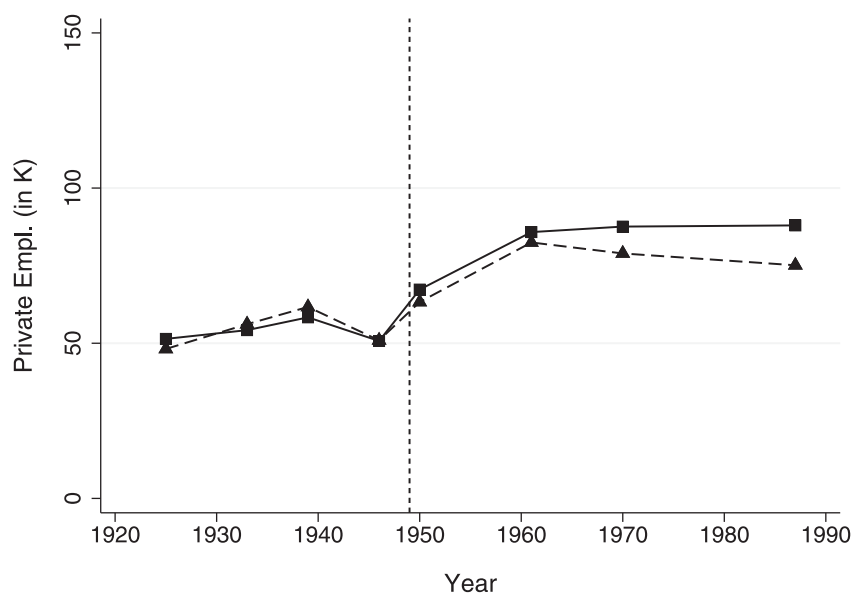

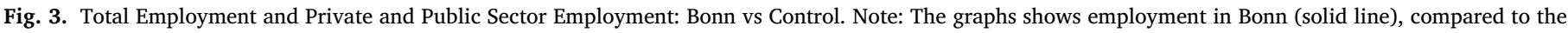

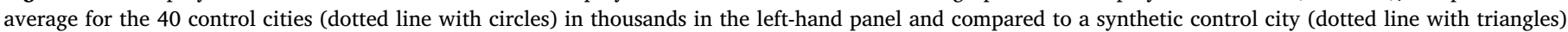

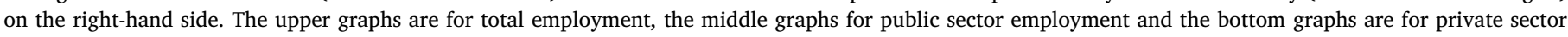

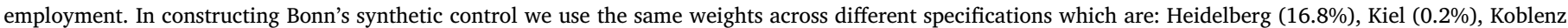
(34.6\%), Mannheim (4.7\%), Münster (8.1\%), Stuttgart (7.0\%), Wiesbaden (25.4\%), and Wilhelmshaven (3.2\%). See the main text for further details. 

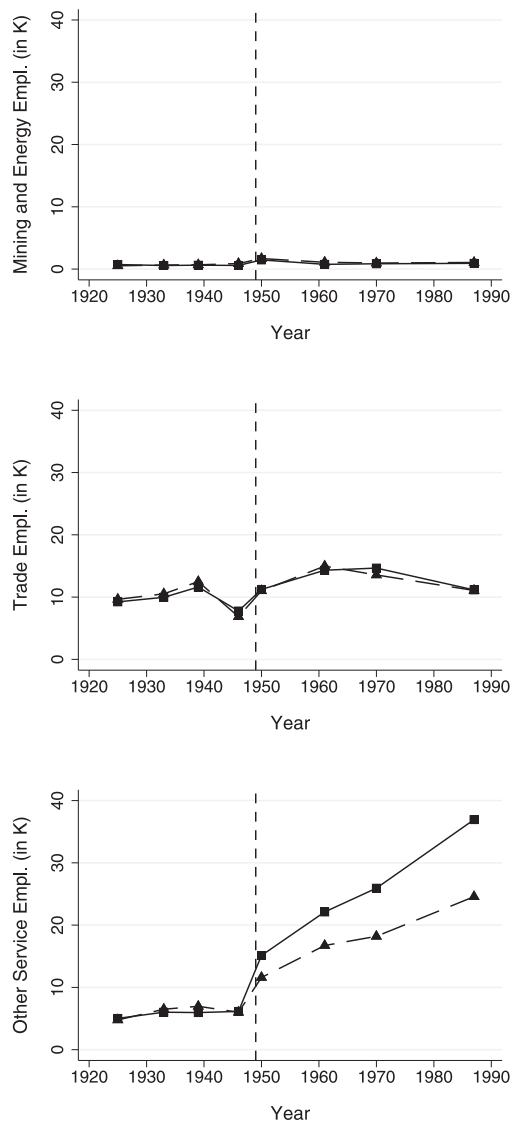
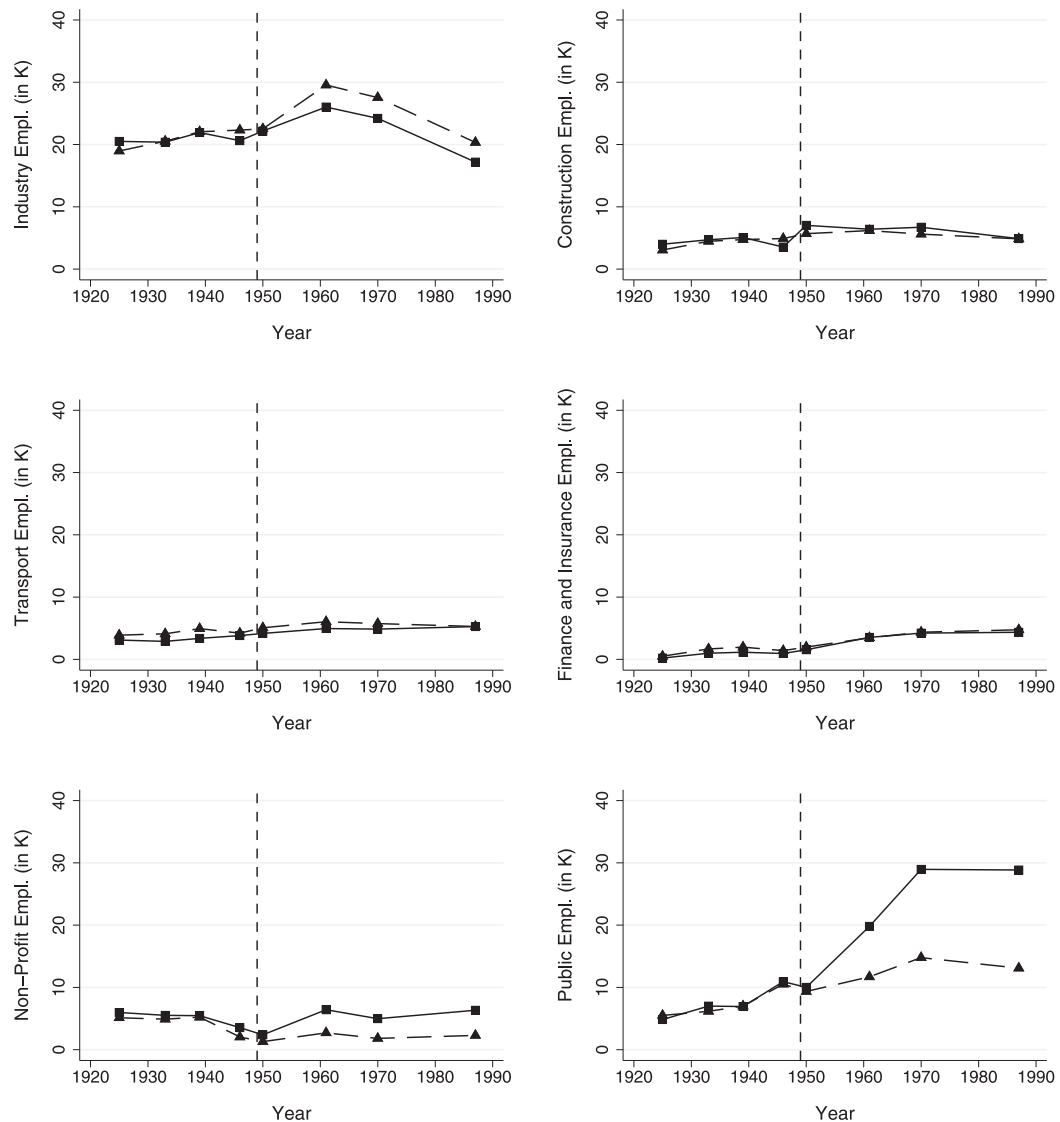

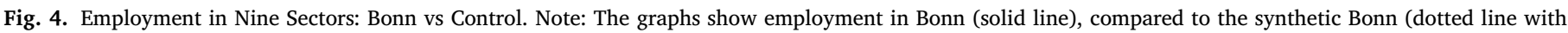

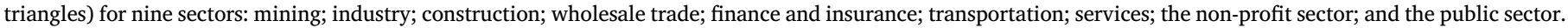
We do not display employment in agriculture as it is very small in the cities in our sample.

age of $12.1 \%$ in the pre-treatment years to $24.7 \%$ in 1987 . In contrast, in the synthetic control the percentage share of public employment in total employment increases from an average of $11.9 \%$ in the pre-treatment years to $14.8 \%$ in 1987 .

The results suggest that while the average of the 40 control cities and the synthetic control are two quite different counterfactuals, they produce fairly similar treatment effects of the arrival of the federal government in Bonn. The similarity of the results across these two very different counterfactuals is reassuring as it suggests that the estimated treatment effects do not depend sensitively on the details of how one constructs a counterfactual for Bonn. In what follows we concentrate on the results using the synthetic Bonn as the counterfactual, which ensures the closest possible fit between Bonn and its counterfactual prior to treatment, but the results would be qualitatively similar if we used the unweighted average of the control cities as the counterfactual for Bonn instead.

To illustrate the magnitude of the effects that we find and to compare the results to the existing literature we convert our treatment effects into simple employment multipliers. Dividing the treatment effect of the arrival of the federal government in Bonn on private sector employment (using our synthetic control for Bonn as the counterfactual) by the analogous treatment effect on public sector employment, we find that each additional public sector job in Bonn has created approximately 0.86 additional jobs in the private sector by the end of our sample in 1987. This effect is substantially smaller than the results in Moretti (2010) who finds that an additional job in the tradable sector of a US city creates 1.6 additional jobs in the city's non-tradable sector, with even larger multiplier effects for additional skilled jobs. There are a number of reasons why the employment spillovers from additional public employment could be substantially smaller than that of additional manufacturing em- ployment. For example, input-output linkages between the manufacturing sector and other sectors may attract additional employment to a location while the public sector plausibly has much smaller input-output linkages. Our multiplier is larger than the multiplier of 0.21 for total private sector employment estimated by Faggio and Overman (2014) in their preferred specification, which is insignificantly different from zero in their data. One reason for this could be that they estimate a short-run multiplier using changes between 2003 and 2007. Consistent with this we find a multiplier of 0.49 using our data up to 1960 and of 0.66 using our data up to 1970.

\subsection{Heterogeneity across different parts of the private sector}

The results so far show that public employment in Bonn has increased substantially after the arrival of the federal government in Bonn while the increase in private sector employment has been more modest. In this section we use our data on the breakdown of overall employment into 10 sectors, discussed in Section 4, to examine the heterogeneity of the changes in employment across sectors. The 10 sectors include agricultural employment, which is so small in all years of our data for Bonn and the 40 control cities that we omit this sector. This leaves nine sectors, one of which is public employment.

The simulations of our model in Fig. 1 show that changes in public sector employment should have a differential impact on private employment in the tradable and non-tradable sector regardless of the strength of amenity or productivity spillovers. In particular, as discussed in more detail in Section 2.4, the impact of an increase in public employment should have a more positive effect on employment in the non-tradable sector compared to employment in the tradable sector. The intuition is that additional public employment creates additional demand for non- 
tradables, which can only be produced locally even if local wages and house prices increase. In contrast higher wages and house prices reduce employment in the local tradable sector, where the increase in local demand can also be met by firms from other cities.

In Fig. 4 we show the development of Bonn and its synthetic control across all nine sectors without taking a stance on the tradability of the output of each of these sectors. The synthetic Bonn is computed using the same fixed weights as before which ensures that the treatment effects across the different sub-sectors add up to the treatment effect on total employment. The figure shows that for a number of the nine sectors there is hardly any visible treatment effect of the arrival of the federal government in Bonn. ${ }^{33}$ However, there are also notable exceptions to this pattern. First, the final panel shows the large increase in public employment in Bonn relative to its synthetic control, which is just reproduced here from Fig. 3. Second, the largest positive treatment effect on private sector employment is in the sector "other service employment". This sector contains a broad set of service employment categories including employment in restaurants, hotels and theaters, business services, personal services and hair dressers. Third, employment in the non-profit sector also experiences a clearly visible increase relative to the synthetic Bonn.

To link the reduced form evidence closer to the model Fig. 5 aggregates private employment across the eight categories shown in Fig. 4 into a tradable and non-tradable sector. The tradable sector is simply industry employment while non-tradable employment is the sum across employment in all service sectors (excluding public employment). While this classification is not perfect it should provide a first-order approximation to the tradability of different sectors. The figure shows that in line with the predictions of our theoretical model the arrival of the federal government in Bonn has had a positive impact on non-tradable employment while the impact on the tradable sector is much smaller and actually negative in our point estimate. Converted into employment multipliers, we find that each additional job in public employment reduces employment in the tradable sector by 0.19 jobs while it creates 1.05 additional jobs in the non-tradable sector. ${ }^{34}$

Fig. 6 investigates the statistical significance of the treatment effects across the different sectors shown in Fig. 4. This graph combines 39 placebo estimates for the cities in our donor pool (grey lines) with the graph for Bonn (black line). Note that we plot 39 instead of 40 placebo graphs because the city with the largest employment (Stuttgart) cannot be reproduced with any combination of cities in our sample. ${ }^{35}$ Each line in this figure shows the difference between a city and its synthetic control. In addition to the 39 placebo graphs, the shaded area encloses the region between the 5th and the 95th percentile of the distribution of placebo graphs. In terms of public employment, Bonn's post-1949 development is more pronounced than that of all other cities. This provides strong evidence for the uniqueness of Bonn's development. Bonn's treatment effect in terms of the non-profit sector employment growth is also clearly statistically significant. The increase in other service employment, which shows the quantitatively largest increase in private sector employment is significant in the early post-war period, but is overtaken

\footnotetext{
${ }^{33}$ We examine the statistical significance of the treatment effects across the different sub-sectors formally below.

34 A potential alternative explanation for the displacement effects in the tradables sector in Bonn relative to the synthetic control could be changes in zoning away from industrial land uses towards public employment to create space for government buildings and to reduce pollution from industrial production. This seems unlikely for two reasons. First, most of the new government buildings in Bonn were built on empty land on the fringes of Bonn. Second, during the 1950 s and 1960s, when we see the biggest treatment effects, Germany's industrial production expanded rapidly and environmental concerns about industrial emissions only became politically salient from the 1970s onwards.

36 This is a well-known limitation of placebo estimates and is typically dealt with by dropping the placebo estimate for the largest member of the donor pool (in this case Stuttgart).
}
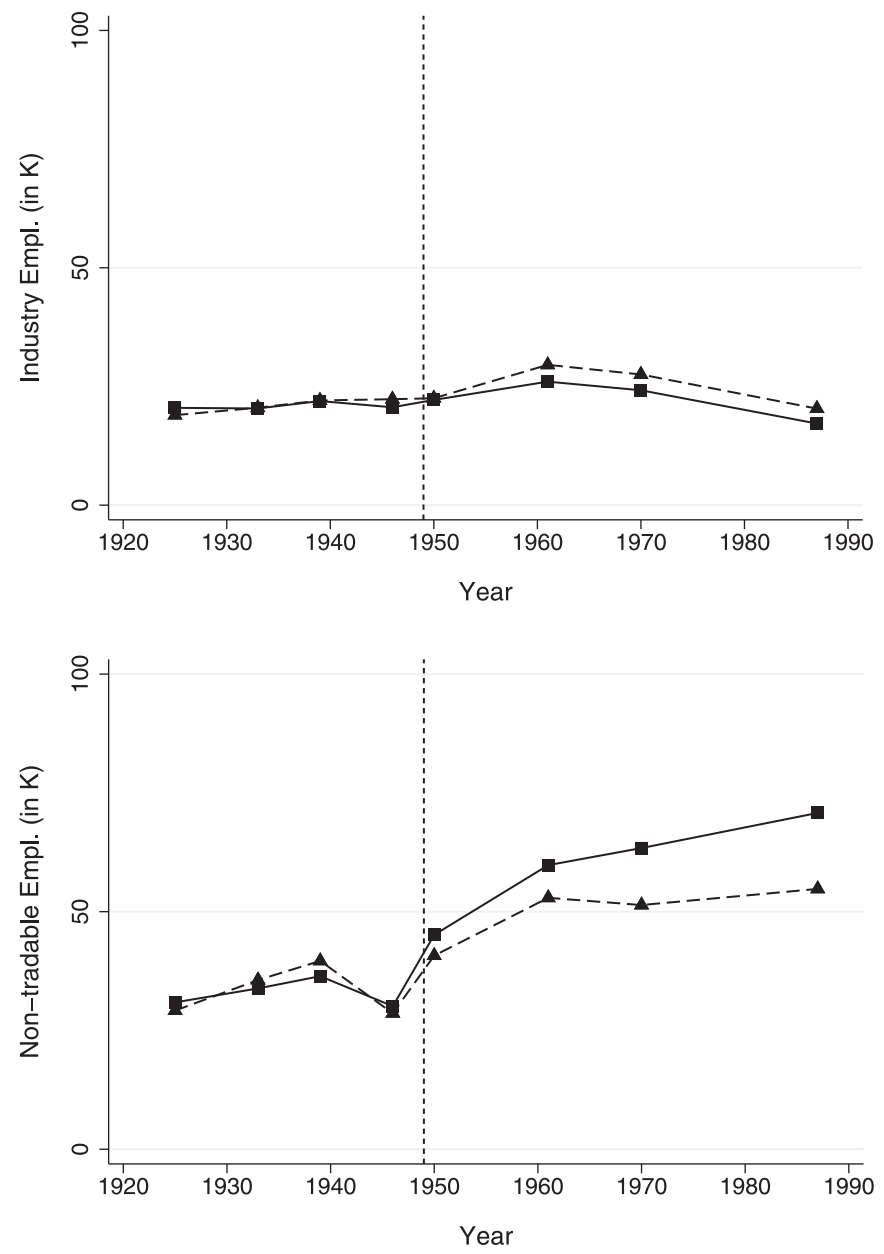

Fig. 5. Private Sector Employment: Tradables vs Non-Tradables. Note: The graph shows the development of tradable and non-tradable employment in Bonn (bold line) and its synthetic control (dotted line). Tradable employment is employment in industry, while non-tradable employment is the sum of all service sector employment (excluding the public sector).

by two control cities in 1987. Finally the small decline in industry employment in Bonn relative to its synthetic control is entirely statistically insignificant with rather noisy placebo treatment effects.

Abadie et al. (2015) suggest an alternative way of estimating the statistical significance of treatment effects in a synthetic control setting by comparing the ratio of the root mean square prediction error (RMSPE) before and after treatment. In particular, we compute both for Bonn and all placebo estimates the RMSPE before and after 1949:

$R M S P E=\left(\frac{1}{T_{p}} \sum_{t_{p}=1}^{T_{p}}\left(Y_{1 t}-\sum_{j=2}^{J+1} Y_{j t} W_{j}^{*}\right)^{2}\right)^{\frac{1}{2}} \quad p \in\{$ pre, post $\}$

The intuition behind this is to contrast the fit between a city and its synthetic placebo after the treatment with the fit before the treatment. A larger ratio implies a stronger treatment effect. The left-hand panels of Appendix Figure B.5 show this ratio for Bonn and all donor pool cities for the three sectors where Fig. 6 suggests that changes in Bonn are statistically significantly different from zero. The pattern visible in Appendix Figure B.5 is very similar to that in Fig. $6 .{ }^{36}$

\footnotetext{
${ }^{36}$ It is a first sight surprising that the RMSPE ratio for public employment for Karlsruhe and Koblenz are nearly as large as the ratio in Bonn. Figure B.6 of the online technical appendix shows that the increase in public employment in these cities is small compared to Bonn (and in the case of Karlsruhe likely driven
} 

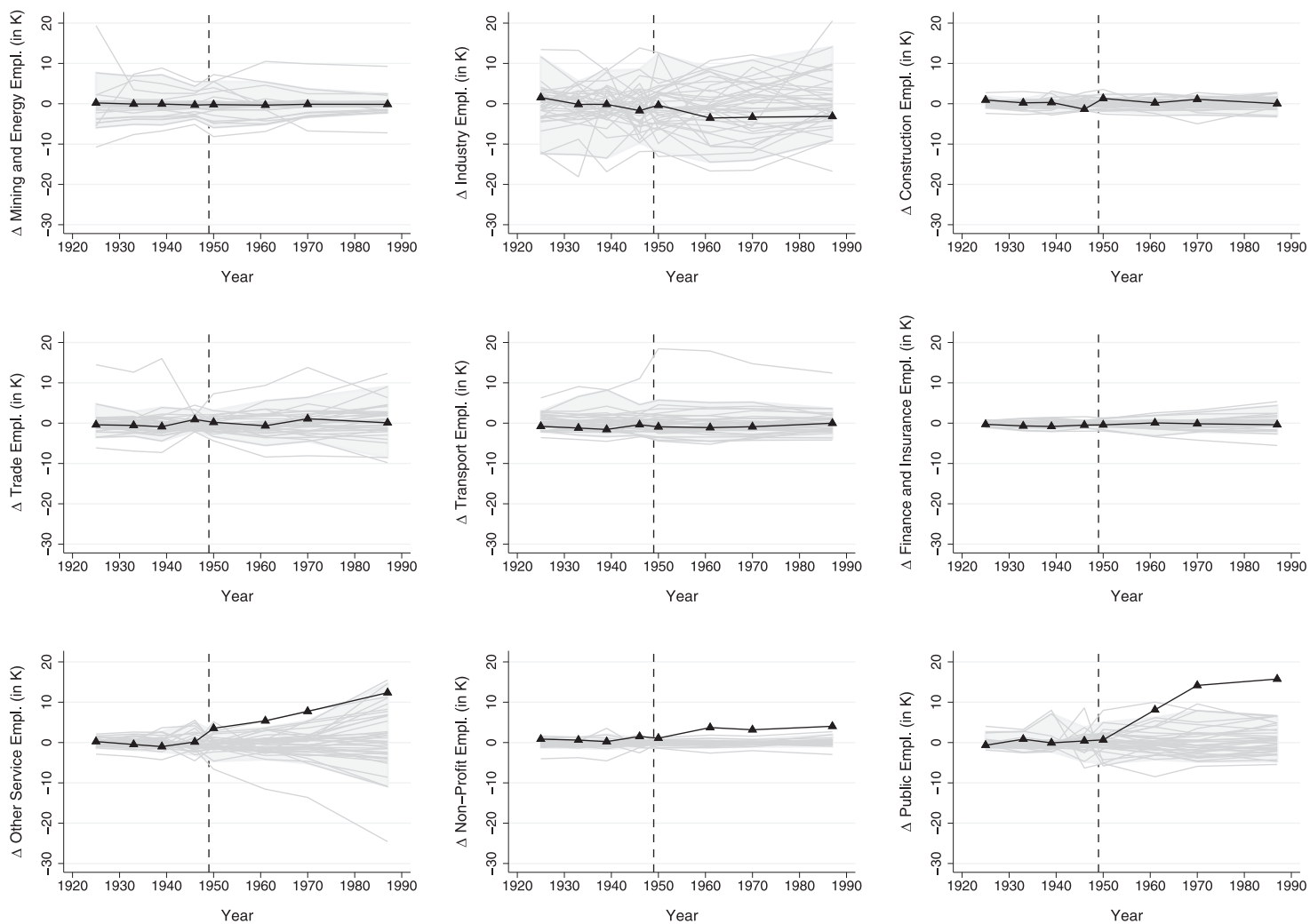

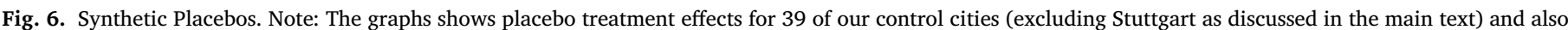

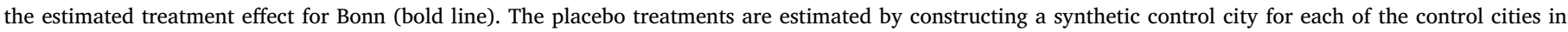

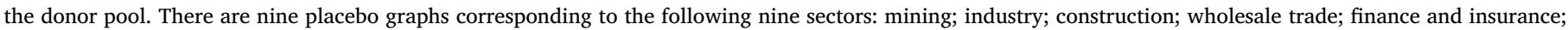
transportation; services; the non-profit sector; and the public sector. We do not display agriculture which is very small as discussed in the main text.

In another robustness check, we examine the sensitivity of our results to the composition of the synthetic control group. The leave-one-out test suggested by Abadie et al. (2015) focuses on the eight locations in the donor pool with a positive weight and re-estimates the baseline model omitting each city with a positive weight in turn. The right-hand panels of Appendix Figure B.5 show the result for the public, non-profit and service sector. The figure shows the baseline graphs for Bonn versus the synthetic control group and the grey lines show the eight placebos where we leave out one of the control locations with a positive weight at a time. The results are robust to these alternative ways of computing the counterfactual, which corroborates the observed similarity between the difference-in-differences and synthetic control group results. ${ }^{37}$

Finally, while Table 1 shows that Bonn is very similar to its synthetic control in terms of three measures of war-time disruption a potential concern is that the remaining differences could have affected the development of Bonn relative to its synthetic control during the post-war period. To address this possibility, we regress the employment variables for all cities in our sample on interactions between year dummies and five measures of war-time disruption. These five measures are the three variables used in our main analysis (the amount of rubble, the fraction of the 1939 housing stock destroyed and proximity to the German-German border) and also a dummy for the Ruhr area, which was heavily destroyed, and dummies for the three West German post-war occupation

by the establishment of the West German constitutional court in this city) and is due to very small RMSPEs for these cities in the pre-war period.

${ }^{37}$ Note that Abadie et al. (2015) also suggest an additional placebo exercise which would assume Bonn became Germany's capital in a period before 1949. Given the comparatively small number of pre-treatment observations in our data it is not possible to implement this idea in our data. zones. We then use the residuals from this regression as an adjusted outcome to construct a synthetic control for Bonn. As shown in Figure B. 1 of the online technical appendix we find very similar results when we compare Bonn to a synthetic control constructed using the residuals from this first stage regression.

In summary, in this section we have shown that comparing Bonn to its synthetic control over the period from 1925 to 1987 reveals that the arrival of the federal government in Bonn after 1949 has resulted in a substantial increase in public employment. At the same time the increase in private employment has been comparatively modest and has been concentrated in the non-tradable sector, while industrial employment in Bonn has experienced a small but statistically insignificant decline. We now analyze the possible mechanisms suggested by our theoretical model that link the development of public and private sector employment in a location.

\section{Mechanisms}

The previous section has shown that in the wake of the arrival of the federal government in Bonn, the city has experienced a dramatic expansion in total employment. However, this expansion was driven by a large expansion in public employment, while private sector employment has increased more modestly. In this section, we interpret this finding in the light of our theoretical model and provide evidence for the mechanisms emphasized by the model. First, we provide some suggestive direct evidence for the amenity and productivity spillovers from public to private employment that the model postulates. Second, we show that proxies for long-term changes in wages are in line with the predictions of the model. Third, we provide evidence that house prices in Bonn responded in the way predicted by the model. Finally, we undertake a simple quan- 
Table 2

Proxies for Amenity Spillovers.

\begin{tabular}{|c|c|c|c|c|c|}
\hline & $\begin{array}{l}\text { (1) } \\
\text { Logarithm of } \\
\text { Cultural } \\
\text { Expenditure }\end{array}$ & $\begin{array}{l}\text { (2) } \\
\text { Logarithm of } \\
\text { Total City } \\
\text { Expenditure }\end{array}$ & $\begin{array}{l}\text { (3) } \\
\text { Logarithm of } \\
\text { Theater } \\
\text { Budgets }\end{array}$ & $\begin{array}{l}\text { (4) } \\
\text { Logarithm of } \\
\text { Number of } \\
\text { Actors }\end{array}$ & $\begin{array}{l}\text { (5) } \\
\text { Logarithm of } \\
\text { Wage Bill } \\
\text { of Actors }\end{array}$ \\
\hline Bonn & $\begin{array}{l}0.553 * * * \\
(0.085)\end{array}$ & $\begin{array}{l}0.086^{*} \\
(0.044)\end{array}$ & $\begin{array}{l}0.665 * * * \\
(0.087)\end{array}$ & $\begin{array}{l}-0.071 \\
(0.118)\end{array}$ & $\begin{array}{l}0.807^{* * * *} \\
(0.109)\end{array}$ \\
\hline Log Population & $\begin{array}{l}1.048^{* * *} \\
(0.115)\end{array}$ & $\begin{array}{l}1.006^{* * *} \\
(0.094)\end{array}$ & $\begin{array}{l}0.732^{* * *} \\
(0.136)\end{array}$ & $\begin{array}{l}0.487^{* * *} \\
(0.220)\end{array}$ & $\begin{array}{l}0.612^{* * *} \\
(0.180)\end{array}$ \\
\hline University Town & $\begin{array}{l}0.560^{* * * *} \\
(0.117)\end{array}$ & $\begin{array}{l}0.154 \\
(0.095)\end{array}$ & $\begin{array}{l}0.330^{* * *} \\
(0.127)\end{array}$ & $\begin{array}{l}0.144 \\
(0.195)\end{array}$ & $\begin{array}{l}0.392^{* *} \\
(0.162)\end{array}$ \\
\hline State Capital & $\begin{array}{l}0.005 \\
(0.094)\end{array}$ & $\begin{array}{l}0.102 \\
(0.157)\end{array}$ & $\begin{array}{l}0.188 \\
(0.178)\end{array}$ & $\begin{array}{l}0.116 \\
(0.181)\end{array}$ & $\begin{array}{l}0.225 \\
(0.185)\end{array}$ \\
\hline $\begin{array}{l}\text { Observations } \\
\text { R-squared }\end{array}$ & $\begin{array}{l}41 \\
0.793\end{array}$ & $\begin{array}{l}39 \\
0.800\end{array}$ & $\begin{array}{l}33 \\
0.676\end{array}$ & $\begin{array}{l}33 \\
0.310\end{array}$ & $\begin{array}{l}32 \\
0.588\end{array}$ \\
\hline & $\begin{array}{l}\text { (6) } \\
\text { Logarithm of } \\
\text { Number of } \\
\text { Theater Visitors }\end{array}$ & $\begin{array}{l}\text { (7) } \\
\text { Logarithm of } \\
\text { Number of } \\
\text { Artists }\end{array}$ & $\begin{array}{l}\text { (8) } \\
\text { Logarithm of } \\
\text { Number of } \\
\text { Doctors }\end{array}$ & $\begin{array}{l}\text { (9) } \\
\text { Logarithm of } \\
\text { Number of } \\
\text { Hospital Beds }\end{array}$ & $\begin{array}{l}(10) \\
\text { Logarithm of } \\
\text { Class } \\
\text { Size }\end{array}$ \\
\hline Bonn & $\begin{array}{l}-0.026 \\
(0.096)\end{array}$ & $\begin{array}{l}0.235^{* * * *} \\
(0.082)\end{array}$ & $\begin{array}{l}0.233^{* * *} \\
(0.061)\end{array}$ & $\begin{array}{l}0.281^{* * *} \\
(0.048)\end{array}$ & $\begin{array}{l}0.022 \\
(0.023)\end{array}$ \\
\hline Log Population & $\begin{array}{l}0.536^{* * * *} \\
(0.169)\end{array}$ & $\begin{array}{l}1.008^{* * * *} \\
(0.172)\end{array}$ & $\begin{array}{l}0.735 * * * \\
(0.075)\end{array}$ & $\begin{array}{l}0.526^{* * * *} \\
(0.086)\end{array}$ & $\begin{array}{l}0.005 \\
(0.035)\end{array}$ \\
\hline University Town & $\begin{array}{l}0.302^{*} \\
(0.160)\end{array}$ & $\begin{array}{l}0.863^{* * *} \\
(0.205)\end{array}$ & $\begin{array}{l}0.394^{* * *} \\
(0.080)\end{array}$ & $\begin{array}{l}0.440^{* * *} \\
(0.086)\end{array}$ & $\begin{array}{l}-0.094^{* * *} \\
(0.027)\end{array}$ \\
\hline State Capital & $\begin{array}{l}0.182 \\
(0.163)\end{array}$ & $\begin{array}{l}0.240 \\
(0.238)\end{array}$ & $\begin{array}{l}0.222 \\
(0.134)\end{array}$ & $\begin{array}{l}0.081 \\
(0.094)\end{array}$ & $\begin{array}{l}0.073 \\
(0.047)\end{array}$ \\
\hline Observations & 33 & 41 & 41 & 41 & 41 \\
\hline R-squared & 0.491 & 0.698 & 0.836 & 0.761 & 0.238 \\
\hline
\end{tabular}

Notes: All columns report OLS regressions of the natural logarithm of a city-specific amenity measure on a dummy for Bonn and controls for the natural logarithm of population, a university town dummy and a state capital dummy. Differences in the number of observations result from missing observations for the city state Bremen with its two cities Bremen and Bremerhaven (Column 2), missing information for theater outcomes in Solingen, Remscheid, Recklinghausen, Offenbach, Mülheim, Ludwigshafen, Herne and Bottrop (Columns 2, 4, 6), and missing wage information for artists in Heidelberg (Column 5). Artists in Column (7) include musicians, performing artists and graphical artists. Robust standard errors reported in parenthesis. ${ }^{* * *} \mathrm{p}<0.01,{ }^{* *} \mathrm{p}<0.05,{ }^{*} \mathrm{p}<0.10$

titative analysis of the model to see for which spillover parameters the model best fits the reduced form evidence.

\subsection{Amenity spillovers}

The two key spillovers emphasized by the model are amenity and productivity spillovers from public to private sector employment. In this section we provide some suggestive evidence that there are likely to be substantial amenity spillovers from public employment in Bonn. Glaeser et al. (2001) discuss four consumption amenities in cities that they consider to be key to urban success. First, the size and diversity of local services and consumer goods including restaurants and live performance theaters. Second, aesthetics and the physical setting which involves the built environment as well as the natural environment. Third, the quality of public services including good schools and low crime rates. Finally, the speed of public transportation to facilitate commuting. While some of the these amenities such as the natural environment are difficult to change, most can be changed through local interventions.

Table 2 shows a set of simple cross-sectional regressions which compare Bonn in 1987 to the control cities for a number of proxies for local amenities in the spirit of Glaeser et al. (2001). We regress the natural logarithm of a proxy for local amenities on a university town dummy, a state capital dummy and the natural logarithm of 1987 population. Across many of these regressions Bonn has substantially higher values of amenities than the control group of cities. Column (1), for example, suggests that cultural spending by the city of Bonn is around $50 \%$ higher than in the control group of cities. Column (2) shows that total expenditure in Bonn is less than $10 \%$ higher than in the control group, so the substantially higher expenditure on culture implies a higher share of spending on cultural amenities in Bonn. Columns (3) to (7) shed more light on the cultural sector. Columns (3), (4) and (5) together suggest that Bonn has substantially larger expenditure on theaters, which are not driven by a larger employment of actors, but by a higher wage bill. If higher wages of actors in Bonn reflect a higher quality of actors, Bonn staged better productions than comparable cities. Column (6), in turn, suggests that these high-quality productions are not attended by more visitors, though. It is also instructive to look at the number of artists more broadly. While theaters are generally publicly funded, the number of artists comprises both those employed in public institutions and those who are self-employed or dependent employees in the private sector. A larger number of artists in Bonn in Column (7) suggests that Bonn offers a richer (or more high-quality) cultural environment overall. Going beyond the cultural sector, Columns (8) and (9) look at medical provision. Bonn has a larger number of doctors and a larger number of hospital beds than the control cities. Finally, turning to schooling quality, for which we use the student-teacher ratio as a proxy, Bonn does not seem to stand out in this dimension as we find no statistically significant difference between Bonn and the control cities. While these regressions are simple cross-sectional regressions, they provide suggestive evidence that Bonn offers a substantially different set of amenities than other German cities of a similar size. ${ }^{38}$

It is unfortunately not possible to compile comparable pre-war data for the same set of amenity proxies that we observe in 1987 and we

\footnotetext{
38 In Table B.1. of the online technical appendix we report the same regressions with all outcomes but Column (10) in per-capita terms instead of controlling for the natural logarithm of population and find qualitatively similar results.
} 
Number of school classes 1929

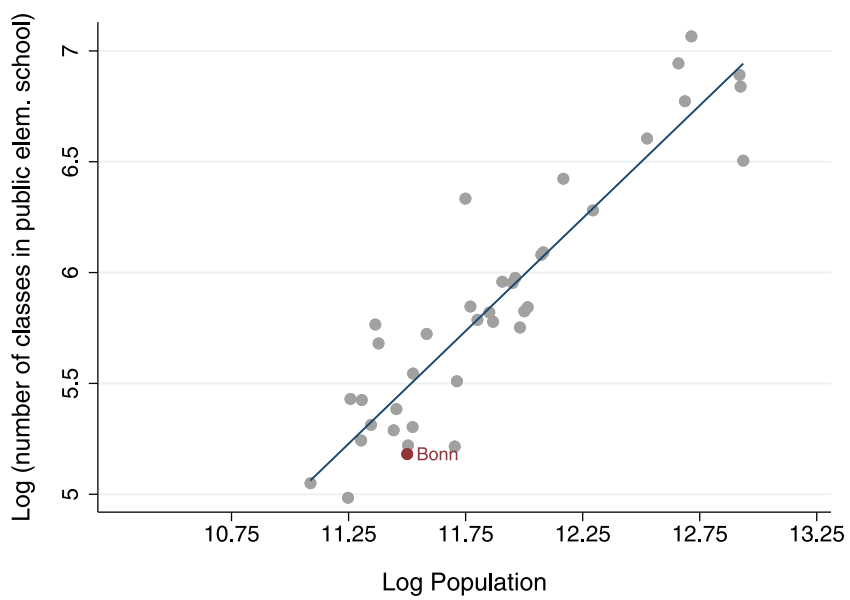

Number of theater seats 1929/30

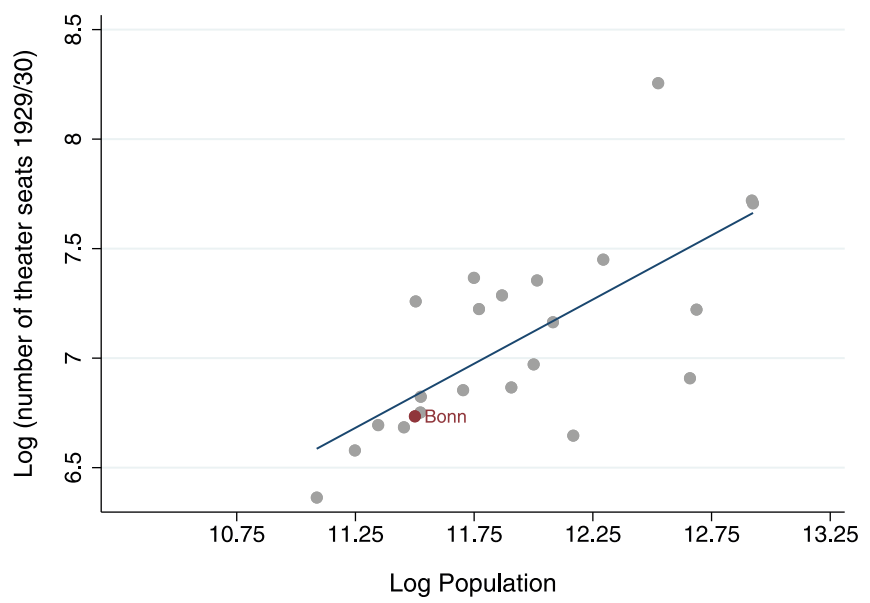

Student teacher ratios 1929

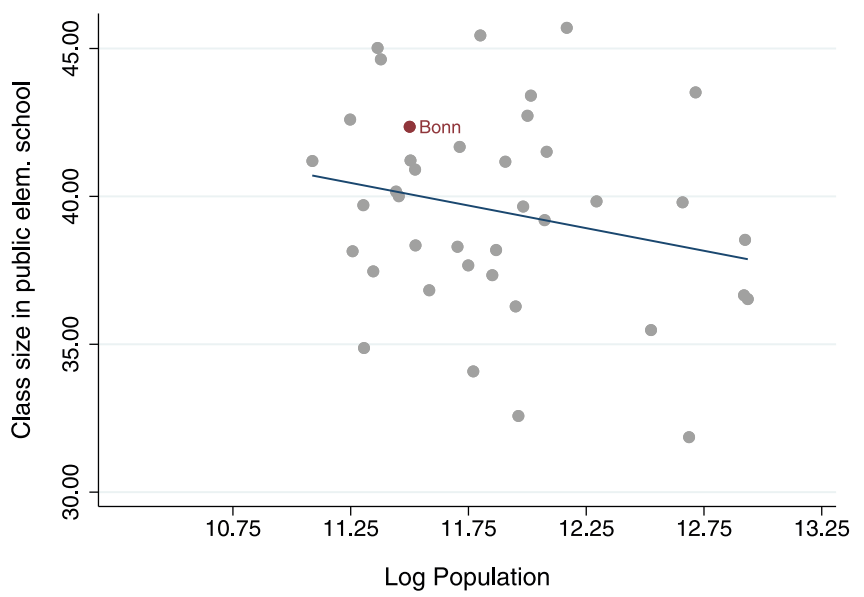

Number of theater shows 1929/30

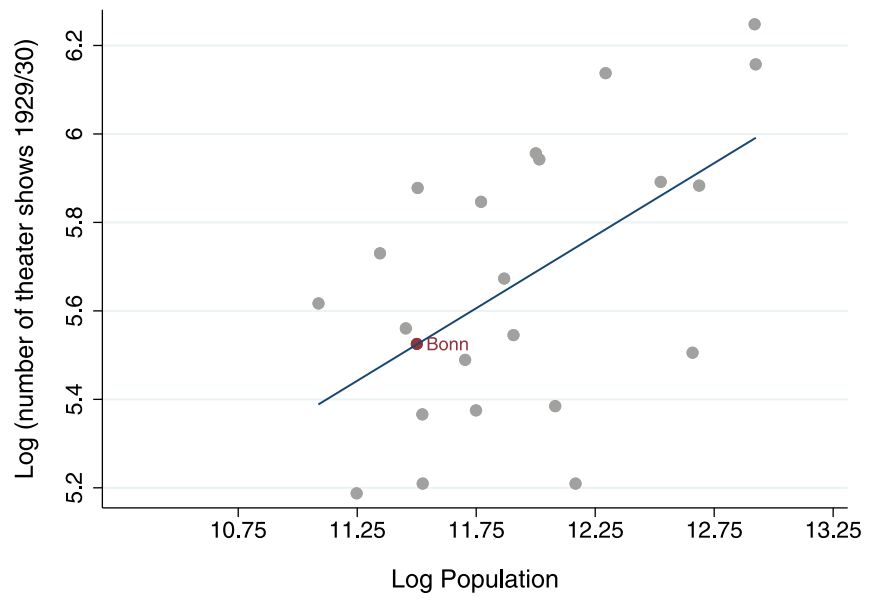

Fig. 7. Amenities before the Second World War. Notes: The graphs shows proxies for amenities before the Second World War against city size in 1939.

therefore cannot compare the change in these proxies in Bonn to the change in the synthetic control for Bonn. We have, however, been able to find data for $1929 / 1930$ for a smaller number of similar proxies for amenities before the Second World War. This data is shown in Fig. 7 which scatters the pre-war data for the number of classrooms in primary schools, the student-teacher ratio, the number of theater seats and the number of theater shows against the 1939 population of each city in our sample together with a linear regression. The figure shows that across all of these proxies for pre-war amenities Bonn was if anything marginally below the average of the control cities. In particular it has fewer classrooms and somewhat larger class sizes than the average city in our sample conditional on population. The number of theater seats and theater shows lies almost exactly on the regression line. This evidence suggests that Bonn did not have better amenities before the Second World War, consistent with the idea that the higher values of the amenities proxies that we observe in Bonn in 1987 are indeed caused by the arrival of the federal government in Bonn and are not due to pre-existing differences between Bonn and the control cities.

\subsection{Productivity spillovers}

We now turn to potential productivity spillovers from increased public employment in Bonn. It would be ideal to investigate this question using firm-level productivity estimates for firms in Bonn and the control group. Unfortunately, firm-level data to estimate firm-level productivity is not available for the time under investigation, neither from national statistics nor from AMADEUS (a European subset of the ORBIS firm database by Bureau van Dijk). ${ }^{39}$ In the absence of data that would allow us to estimate firm-level productivity regressions, we present regressions of city level gross value added in the industry sector and the trade and transportation sector in 1988 (Gemeinschaftsveröffentlichung der Statistischen Landesämter, 1991) on controls for university town status, state capital status, the natural logarithm of population and a dummy variable for Bonn.

The regressions in Table 3 show a clear picture. There is no evidence that gross value added per worker in Bonn is higher than in the control group. Instead, we find negative and statistically significant differences between gross value added per worker in Bonn and the control group of cities in the industry sector and an insignificant effect that is close to zero for the trade and transportation sector. With the data limitations in mind, Columns (1) to (3) suggest that industry gross value added in Bonn is between $27-39 \%$ lower than in the control group. For the trade and transportation sector, the unconditional specification in Col-

\footnotetext{
39 To the best of our knowledge, there is only one study by Bernard and Wagner (1997) that uses plant-level data in this time. However, the study is restricted to one federal state, Lower Saxony, and comparable data for other states is not available before 1995. After that, the research data center of the federal states' statistical offices provides access to some official firm data (see Malchin and Voshage, 2009).
} 
Table 3

Gross Value Added per Worker Across Cities.

\begin{tabular}{|c|c|c|c|c|c|c|c|c|c|}
\hline & & (2) & \multirow[t]{3}{*}{ (3) } & & (5) & \multirow[t]{2}{*}{ (6) } & & (8) & \multirow{2}{*}{ (9) } \\
\hline & \multicolumn{2}{|l|}{ Industry } & & \multicolumn{2}{|c|}{ Trade/Transportation } & & \multicolumn{2}{|c|}{ Industry \& Trade/Transport. } & \\
\hline & \multicolumn{2}{|c|}{ Gross Value Added, 1988} & & \multicolumn{3}{|c|}{ Gross Value Added, 1988} & \multicolumn{3}{|c|}{ Gross Value Added, 1988} \\
\hline Bonn & $\begin{array}{l}-0.272^{* * *} \\
(0.062)\end{array}$ & $\begin{array}{l}-0.394^{* * *} \\
(0.077)\end{array}$ & $\begin{array}{l}-0.374^{* * *} \\
(0.082)\end{array}$ & $\begin{array}{l}0.168^{* * * *} \\
(0.052)\end{array}$ & $\begin{array}{l}-0.024 \\
(0.050)\end{array}$ & $\begin{array}{l}0.013 \\
(0.052)\end{array}$ & $\begin{array}{l}-0.117^{* *} \\
(0.056)\end{array}$ & $\begin{array}{l}-0.251^{* * *} \\
(0.060)\end{array}$ & $\begin{array}{l}-0.231^{* * *} \\
(0.069)\end{array}$ \\
\hline University Town & & $\begin{array}{l}0.313^{* *} \\
(0.125)\end{array}$ & $\begin{array}{l}0.330^{* *} \\
(0.133)\end{array}$ & & $\begin{array}{l}0.489^{* * * *} \\
(0.073)\end{array}$ & $\begin{array}{l}0.518^{* * * *} \\
(0.072)\end{array}$ & & $\begin{array}{l}0.343^{* * *} \\
(0.108)\end{array}$ & $\begin{array}{l}0.359^{* * * *} \\
(0.110)\end{array}$ \\
\hline State Capital & & $\begin{array}{l}0.028 \\
(0.108)\end{array}$ & $\begin{array}{l}0.060 \\
(0.127)\end{array}$ & & $\begin{array}{l}0.029 \\
(0.069)\end{array}$ & $\begin{array}{l}0.088 \\
(0.097)\end{array}$ & & $\begin{array}{l}0.021 \\
(0.085)\end{array}$ & $\begin{array}{l}0.054 \\
(0.105)\end{array}$ \\
\hline Log Population & & & $\begin{array}{l}-0.067 \\
(0.135)\end{array}$ & & & $\begin{array}{l}-0.122 \\
(0.084)\end{array}$ & & & $\begin{array}{l}-0.068 \\
(0.099)\end{array}$ \\
\hline Observations & 41 & 41 & 41 & 41 & 41 & 41 & 41 & 41 & 41 \\
\hline R-squared & 0.007 & 0.572 & 0.597 & 0.012 & 0.173 & 0.178 & 0.003 & 0.246 & 0.252 \\
\hline
\end{tabular}

Notes: All columns report OLS regressions of the logarithm of city specific gross value added per worker at market prices on a dummy for Bonn, a university town dummy, a state capital dummy, and the logarithm of population. Robust standard errors reported in parenthesis. ${ }^{* * *} \mathrm{p}<0.01,{ }^{* *} \mathrm{p}<0.05,{ }^{*} \mathrm{p}<0.10$

Table 4

Wages.

\begin{tabular}{|c|c|c|c|c|c|c|}
\hline & & (2) & (3) & (4) & & (6) \\
\hline & \multicolumn{4}{|l|}{ Baseline } & \multirow{2}{*}{$\begin{array}{l}\text { Imputed Wage } \\
\text { Log Wage }\end{array}$} & \multirow{2}{*}{$\begin{array}{l}\text { Pop Control } \\
\text { Log Wage }\end{array}$} \\
\hline & Log Wage & Log Wage & Log Wage & Log Wage & & \\
\hline Bonn & $\begin{array}{l}-0.020^{* *} \\
(0.008)\end{array}$ & $\begin{array}{l}-0.003 \\
(0.009)\end{array}$ & $\begin{array}{l}0.009 \\
(0.006)\end{array}$ & $\begin{array}{l}0.024^{* * *} \\
(0.005)\end{array}$ & $\begin{array}{l}0.025 * * * \\
(0.005)\end{array}$ & $\begin{array}{l}0.017 * * * \\
(0.004)\end{array}$ \\
\hline Experience & & $\begin{array}{l}0.036^{* * *} \\
(0.002)\end{array}$ & $\begin{array}{l}0.032^{* * * *} \\
(0.001)\end{array}$ & $\begin{array}{l}0.032^{* * *} \\
(0.001)\end{array}$ & $\begin{array}{l}0.032^{* * *} \\
(0.001)\end{array}$ & $\begin{array}{l}0.032^{* * * *} \\
(0.001)\end{array}$ \\
\hline Expericence squared & & $\begin{array}{l}-0.001^{* * *} \\
(0.000)\end{array}$ & $\begin{array}{l}-0.001^{* * *} \\
(0.000)\end{array}$ & $\begin{array}{l}-0.001^{* * * *} \\
(0.000)\end{array}$ & $\begin{array}{l}-0.001 * * * \\
(0.000)\end{array}$ & $\begin{array}{l}-0.001^{\text {**** }} \\
(0.000)\end{array}$ \\
\hline Female & & $\begin{array}{l}-0.179^{* * *} \\
(0.014)\end{array}$ & $\begin{array}{l}-0.152^{* * *} \\
(0.009)\end{array}$ & $\begin{array}{l}-0.152^{* * *} \\
(0.009)\end{array}$ & $\begin{array}{l}-0.140^{* * *} \\
(0.009)\end{array}$ & $\begin{array}{l}-0.152^{* * *} \\
(0.009)\end{array}$ \\
\hline Foreigner & & $\begin{array}{l}-0.040^{* * *} \\
(0.013)\end{array}$ & $\begin{array}{l}-0.052^{* * * *} \\
(0.011)\end{array}$ & $\begin{array}{l}-0.048^{* * *} \\
(0.009)\end{array}$ & $\begin{array}{l}-0.050^{* * *} \\
(0.009)\end{array}$ & $\begin{array}{l}-0.048^{* * *} \\
(0.009)\end{array}$ \\
\hline Log Income Tax pc 1937 & & & & $\begin{array}{l}0.038^{* *} \\
(0.015)\end{array}$ & $\begin{array}{l}0.039 * * \\
(0.015)\end{array}$ & $\begin{array}{l}0.025^{* *} \\
(0.011)\end{array}$ \\
\hline Log Population & & & & & & $\begin{array}{l}0.018^{*} \\
(0.009)\end{array}$ \\
\hline Education Dummies & No & Yes & Yes & Yes & Yes & Yes \\
\hline Industry Fixed Effects & No & No & Yes & Yes & Yes & Yes \\
\hline Observations & 166,282 & 157,161 & 157,107 & 157,107 & 157,107 & 157,107 \\
\hline R-squared & 0.198 & 0.437 & 0.533 & 0.535 & 0.606 & 0.535 \\
\hline
\end{tabular}

Notes: Column (1) captures the raw wage difference between Bonn and the control cities. In Column (2) we control for various observable worker characteristics including dummies for three education levels and interactions between these variables (which are not shown). Column (3) also controls for 88 industry fixed effects. Column (4) controls for pre-war income tax receipts. In Column (5) we do not use a dummy for top coded income observations but impute these instead. in Column (6) we also control for the logarithm of population. See the main text for more detail. Standard Errors are clustered at the level of each city. ${ }^{* * *} \mathrm{p}<0.01,{ }^{* *} \mathrm{p}<0.05$, ${ }^{*} \mathrm{p}<0.10$

umn (4) suggests a $17 \%$ higher gross value added in Bonn than in the control group but the size of this effect drops to close to zero and becomes statistically insignificant once we add controls. Finally, when we combine both sectors in Columns (7) to (9), the estimated difference in gross value added suggests a $12-25 \%$ lower value in Bonn than in the control group. Given the crude data and the lack of information about the cities' productivity before the Second World War, we cautiously interpret these regressions as suggestive evidence that public employment is unlikely to produce productivity spillovers that benefit private sector firms.

\subsection{Nominal wages}

To investigate how the large increase in employment affected nominal wages in Bonn, we use a $5 \%$ random sub-sample of wages from the Historic Employment and Establishment Statistics (HES) database for 1987 and estimate whether wages in Bonn are higher compared to the control cities. The HES data report workers' daily wages, their industry and occupation, and socio-demographic characteristics such as educational attainment, gender, age, and place of work. The wage information is very reliable, since it is used to determine social insurance contributions. One drawback of the data is that wages are censored due to the limit for compulsory social insurance payments. ${ }^{40}$ To control for this, we include a dummy variable for observations where wages are top-coded. Alternatively, we have also imputed the truncated wages following Gartner (2005). The data excludes civil servants and self-employed individuals which are not covered by the social security system. ${ }^{41}$

Table 4 shows the results of the wage regressions. In Column (1), we present a bivariate regression showing that wages are, on average, $2 \%$ lower in Bonn than in the set of 40 control cities. In Columns (2) to (4), we add a number of control variables. In Column (2), we

\footnotetext{
40 This affects only $9.6 \%$ of the observations.

41 We also drop from the sample workers younger than 18 or older than 65 and we also exclude all individuals in training and in part-time employment since there is no information on hours worked in the HES.
} 
add experience and experience squared, education, gender and a foreigner dummy. Additionally, we include interactions between experience, experience squared, gender, education and nationality as suggested by Beaudry et al. (2012). In Column (3), we add dummies for 88 two-digit industries. In Column (4) we add a control for the natural logarithm of income tax revenue per capita for 1937 in each city in the sample. This variable controls for potential pre-existing differences in income before Bonn became capital. One can think of this regression as a quasi difference-in-differences regression. In Column (4) the Bonn dummy is positive and statistically significant suggesting that wages in Bonn were about $2.4 \%$ higher than in the control cities. $^{42}$

The remaining columns of the table consider further robustness checks. In Column (5) we impute the truncated wages following Gartner (2005), which has minimal impact on the results. In Column (6) we also control for the natural logarithm of population. In line with the existing literature the coefficient estimate for total population suggests that larger cities pay somewhat higher nominal wages. The Bonn dummy becomes slightly smaller but remains statistically significant. ${ }^{43}$ Taken together, these results suggest that there has been a small increase in nominal wages in Bonn relative to the control group of cities.

\subsection{House prices}

We now investigate the extent to which house prices have likely responded to a change in employment and hence population in Bonn. Recent work by Combes et al. (2019) exploits data on individual land transactions in French cities to isolate the causal effect of an increase in population on the price of land and, in turn, on the price of housing. They show that in line with the predictions of standard economic geography models of the kind developed in this paper, an inflow of population increases housing prices in a city. Saiz (2010) provides similar estimates for US metropolitan areas.

Comparable data on house or land prices is currently unfortunately not available for Germany as information on real estate transactions is held locally and not reported to a national database. However, we have been able to obtain data from the Association of Real Estate Agents that reports the average price of transactions across four different types of real estate for a number of German cities. Specifically, the data reports the average rental price of new-build flats along with the average purchase price of new-build flats, new-build semi-detached houses and newbuild detached houses. This data is far from perfect as it covers a subset of German cities that only partially overlaps with the cities in our sample, only reports average prices and is unlikely to capture the universe of transactions.

Fig. 8 correlates the natural logarithm of this data with the natural logarithm of population in 1987 for each city for which the Association of Real Estate Agents reports data (which is a somewhat different sample of cities than our control cities) and also shows a linear regression. The figure shows that there is a clear positive correlation between the natural logarithm of the different measures of house prices and the natural logarithm of population. Bonn is close to the regression line for most measures of housing prices reported by the RDM. Taken together this provides suggestive evidence that the dispersion force of higher real estate prices emphasized by our model also seems to be operating in Germany.

\subsection{Quantitative analysis of the model}

We now undertake a simple quantitative analysis of the theoretical model to see whether the model can match the key features of our re-

\footnotetext{
42 Using income tax revenue per capita for 1928 yields very similar results.

43 Note that the population of Bonn is by construction of the sample close to the average population of the cities in the sample and the Bonn dummy should therefore not be substantially correlated with the population control variable.
}

duced form results. In particular, we search for values of the amenity and productivity spillovers ( $\delta$ and $\alpha$ respectively) and the share of total public employment located in Bonn for which the model can best match the reduced form evidence. In doing so, we maintain other parameters of the model, such as the elasticity of substitution, at central values from the existing literature. The simulations in Fig. 1 show that, conditional on the other parameters of the model, the strength of amenity and productivity spillovers and the share of total public employment located in each of the two cities in the model uniquely determine the distribution of public and private employment in our model. Intuitively, the distribution of public employment produces spillovers to the private sector in the model and the strength of these spillovers depends on the values of $\delta$ and $\alpha$.

These three parameters are identified using three moments in the data. The first moment is the increase in the share of public employment in total employment in Bonn relative to the synthetic control city. As discussed in Section 6.1, the share of public employment in Bonn increases by approximately 12.6 percentage points between the pretreatment years and 1987 while the same change in the synthetic control is just under 3 percentage points resulting in a treatment effect of 9.6 percentage points, which we target in the quantitative analysis. The second moment is the increase in private employment in Bonn relative to its synthetic control. As also discussed in Section 6.1 this treatment effect on private employment in Bonn is just under 13,400 workers. For the quantitative analysis we convert this treatment effect into a percentage change to abstract from changes in the overall level of employment in West Germany between the pre-treatment years and 1987. The increase in private employment in Bonn between the pre-treatment years and 1987 is $63.9 \%$ while the same change in the synthetic control is $38.5 \%$, resulting in a treatment effect of $63.9 \%-38.5 \%=25.4 \%$. We target this 25.4 percentage points difference in the model. The third moment is the difference in wages between Bonn and the control cities estimated in Section 7.3 above. The results in Column (4) of Table 4 show that wages in Bonn are $2.4 \%$ higher than in the control cities after controlling for observable worker characteristics and also 1937 differences in income tax per capita receipts across cities. We therefore target a wage difference of $2.4 \%$ in the quantitative analysis.

The intuition of how these moments are able to identify the three parameters is as follows. The change in private employment in Bonn helps to identify the magnitude of a combination of amenity and productivity spillovers. If both of these spillovers are zero, then the increase in public employment in Bonn would reduce total private sector employment in Bonn in the model. Similarly, a high level of these spillovers would make Bonn more attractive for private employment resulting in an increase in private employment. Second, the difference in the share of public employment in total employment between Bonn and the synthetic control city pins down the share of total public employment that is located in Bonn, i.e the inequality in the distribution of public employment across cities. Third, the difference in wages across Bonn and the control cities identifies the relative strength of amenity and productivity spillovers. While both higher productivity and amenity spillovers from public employment increase wages and house prices in the city with more public employment, productivity spillovers have a comparatively stronger effect on wages than amenity spillovers.

To determine the values of these three parameters we perform both a grid search and also use a gradient solver. The grid search considers values for $\alpha$ and $\delta$ between -0.08 and 0.08 in steps of 0.002 and the share of public employment in Bonn between 0.7 and 0.8 in steps of 0.01 , which involves evaluating 72,171 parameter combinations. ${ }^{44}$ Table 5 shows the ten best fit values of amenity and productivity spillovers and the

\footnotetext{
${ }^{44}$ In a first step we evaluated a coarse grid with values of $\alpha$ and $\delta$ between -0.08 and 0.08 and public employment shares between 0.5 and 0.9 , which suggested that the global minimum of the objective function must involve public employment shares between 0.7 and 0.8 .
} 

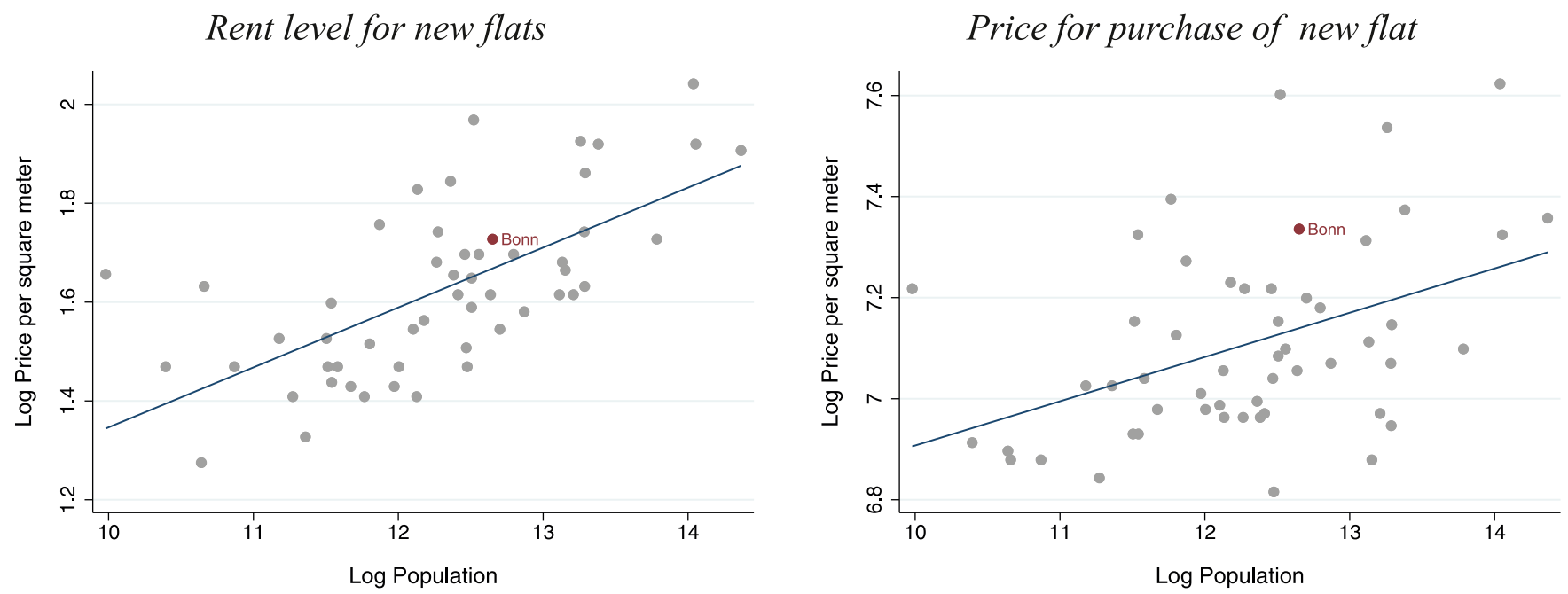

\section{Price for new semi-detached house}
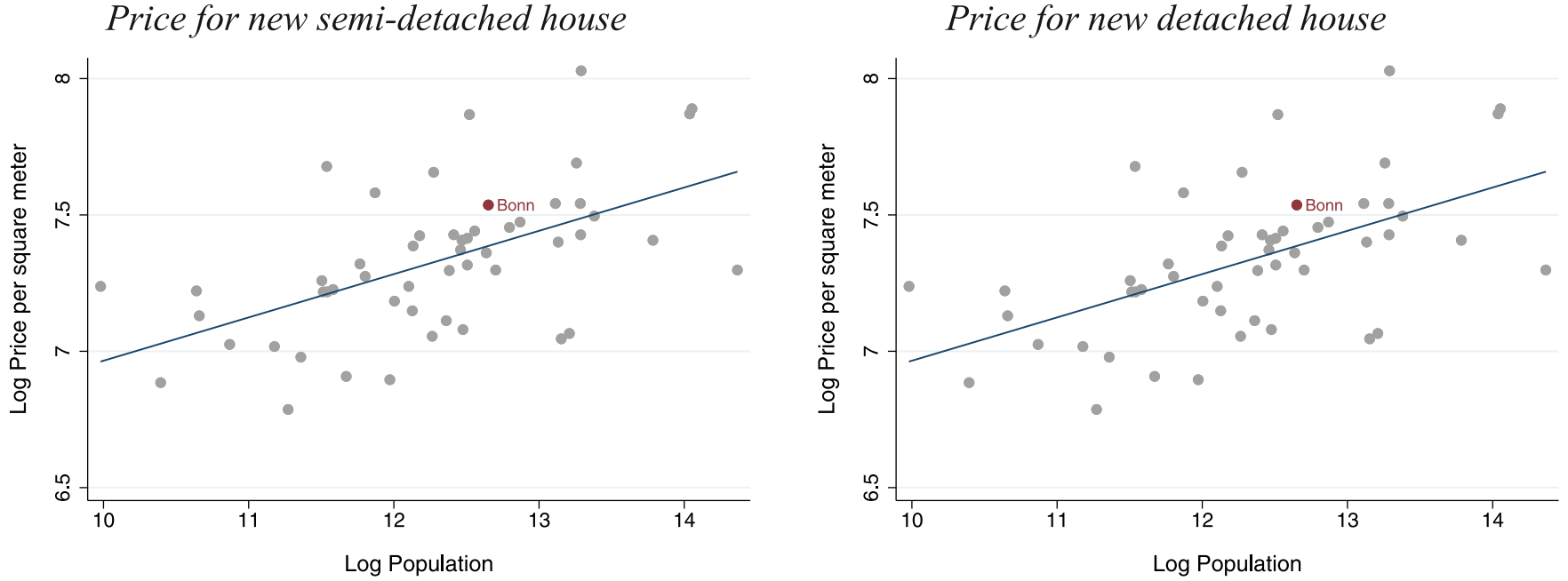

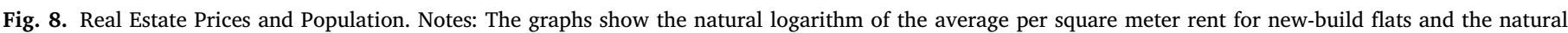

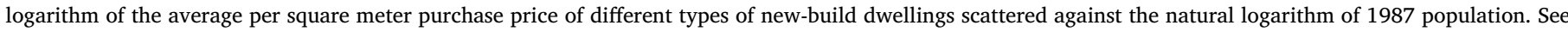
the main text for further details.

share of total public employment located in each of the two cities in the model. For the best fit parameters, the estimated productivity spillovers of public employment are negative but close to zero, while the estimated amenity spillovers of public employment are positive. The point estimates imply that doubling public employment in a city reduces productivity in the private sector by about $0.4 \%$ while amenities in the city increase by about $1.8 \%$. The parameter estimates are fairly similar across the 10 best fit parameter values shown in Table 5 which suggests that the objective function defined by the three moments is wellbehaved and has a unique global minimum. ${ }^{45}$ Finally, we also use a gradient solver to determine the minimum of the objective function and

\footnotetext{
45 To further examine how well these moments identify the magnitude of the productivity and amenity spillovers, Figure B.7 of the online technical appendix shows the objective function for different values of the amenity and productivity spillovers holding the share of public employment constant at the value that minimizes the objective function. The figure suggests that the objective function is well-behaved with a unique minimum. Furthermore, the figure shows that the sum of amenity and productivity spillovers is very tightly identified, while determining the relative strength of amenity and productivity spillovers is harder.
}

find values of $\alpha$ of $-0.0076, \delta$ of 0.0211 and a share of public employment in Bonn of 0.7841 , which is very similar to the best fit parameter combination in the grid search. ${ }^{46,47}$

Overall, the results of the quantitative analysis are consistent with and complement the reduced form evidence on mechanisms. Both the quantitative analysis and the reduced form evidence suggest that the increase in public employment has increased amenities in Bonn but has at best left productivity in the private sector unchanged.

\footnotetext{
${ }^{46}$ We used Matlab's patternsearch algorithm and searched over $\alpha$ and $\delta$ between -0.05 and 0.07 and a share of public employment in Bonn between 0.6 and 0.8. This involved 12,078 iterations to solve the system to a tolerance of 1.0e-7.

47 We undertake the quantitative analysis in this section with our baseline model where labor is perfectly mobile across cities. If we instead assumed that there are frictions to labor mobility across cities despite 40 years of adjustment, we would find even larger amenity spillovers and even more negative productivity spillovers. Intuitively, the model would require larger overall spillovers to explain the observed increase in employment in Bonn, but to match the small increase in nominal wages this increase in spillovers has to be biased towards amenity spillovers.
} 
Table 5

Best Fit Parameters Quantitative Analysis.

\begin{tabular}{|c|c|c|c|c|c|c|}
\hline & (2) & (3) & (4) & (5) & (6) & (7) \\
\hline $\begin{array}{l}\text { Productivity } \\
\text { Spillover } \\
(\alpha)\end{array}$ & $\begin{array}{l}\text { Amenity } \\
\text { Spillover } \\
(\delta)\end{array}$ & $\begin{array}{l}\text { Share of Total } \\
\text { Public Empl. } \\
\text { in City } 1\end{array}$ & $\begin{array}{l}\text { Treatm. Eff. } \\
\text { Private Empl. } \\
\text { (in p.p.) }\end{array}$ & $\begin{array}{l}\text { Treatm. Eff. } \\
\text { Public Empl. } \\
\text { (in p.p.) }\end{array}$ & $\begin{array}{l}\text { Wage } \\
\text { Difference } \\
\text { (in \%) }\end{array}$ & $\begin{array}{l}\text { Sum of } \\
\text { Squared } \\
\text { Differences }\end{array}$ \\
\hline-0.004 & 0.018 & 0.780 & 25.377 & 9.450 & 2.792 & 0.188 \\
\hline-0.006 & 0.020 & 0.780 & 25.914 & 9.399 & 2.597 & 0.408 \\
\hline-0.008 & 0.022 & 0.770 & 25.114 & 9.030 & 2.305 & 0.431 \\
\hline-0.010 & 0.024 & 0.770 & 25.627 & 8.982 & 2.119 & 0.580 \\
\hline-0.002 & 0.016 & 0.780 & 24.841 & 9.500 & 2.988 & 0.626 \\
\hline-0.006 & 0.020 & 0.770 & 24.600 & 9.079 & 2.491 & 0.883 \\
\hline 0.000 & 0.014 & 0.790 & 25.609 & 9.873 & 3.320 & 0.969 \\
\hline-0.002 & 0.016 & 0.790 & 26.168 & 9.821 & 3.114 & 1.210 \\
\hline-0.008 & 0.022 & 0.780 & 26.448 & 9.350 & 2.401 & 1.279 \\
\hline-0.012 & 0.026 & 0.770 & 26.139 & 8.933 & 1.934 & 1.326 \\
\hline
\end{tabular}

Notes: The table shows the 10 best fit parameter combinations for the productivity spillover, amenity spillover and share of public employment in city 1 and the implied values of the three moments in the model. The final column shows the value of the objective function. The empirical moments that we target are 25.4 percentage points in Column (4), 9.6 percentage points in Column (5) and 2.4 percentage points in Column (6). See Section 7.5 in the main text for more detail.

\section{Discussion}

In this section we briefly put our key findings in perspective and draw out some implications. Our finding that the increase in public employment in Bonn led to moderate increases in private sector employment, particularly in the non-tradable sector, is likely to be an upper bound on the multiplier effects of public employment. The creation of a federal government attracts lobbyists, trade associations, diplomats and visitors. More mundane forms of public employment come without most of these side effects and could therefore have smaller multiplier effects on private sector employment. This could also explain why our multiplier effects are somewhat larger than the findings of Faggio and Overman (2014), which we discuss in more detail in Section 6.1 above.

There are at least three suggestive pieces of evidence that only a small part of the expansion of private sector employment in Bonn is driven by the wider impact of Bonn becoming the federal capital. First, foreign diplomats in embassies in Bonn are excluded from our employment counts and therefore do not mechanically inflate non-tradable employment in Bonn. However, diplomats do contribute to local demand for services in Bonn through their consumption expenditures. ${ }^{48}$ Second, our results in Fig. 4 show that employment in the non-profit sector, which includes employment in trade associations and other lobby organizations, is quantitatively small relative to the increase in the category "other service employment", which contains classic non-tradable services such as employment in restaurants, hotels, theaters, business services, personal services and hair dressers. Finally, to assess whether Bonn has been a magnet for visitors, we use data for Bonn and the control cities for the number of hotel nights per capita in each city in 1985. In this data, Bonn only has the eighth largest number of hotel nights per capita, far behind the most visited cities in our donor pool. ${ }^{49}$

Our finding that the estimated effect of increases in public employment on private employment for Bonn is not very large even in the presence of the benefits of becoming the federal capital suggests that policies to relocate more mundane forms of public employment to support lag-

\footnotetext{
48 As diplomats were excluded from both population and employment counts it is difficult to say with any precision how many diplomats were stationed in Bonn. Chbib (2017) mentions contemporary local newspaper reports that approximately 3400 individuals worked in diplomatic missions in Bonn in 1960, rising to 6000 by 1975 .

49 The eight cities with the largest number of hotel nights per capita in 1985 in our sample are (nights per capita in parenthesis): Heidelberg (5.7), Trier (5.3), Wiesbaden (3.6), Würzburg (3.5), Mainz (3.5), Freiburg (3.3), Lübeck (2.9) and Bonn (2.7).
}

ging regions may not be very successful in stimulating private sector development. While a full cost-benefit analysis of such policies is beyond the scope of this paper, this suggests that such policies could be less effective than advocates of such policies may expect.

\section{Conclusion}

This paper uses the creation of the West German government in Bonn in the wake of the Second World as a natural experiment to provide evidence for the effects of public employment on private sector employment. Comparing Bonn to a control group of ex-ante similar cities and a synthetic control city, we find that the substantial increase in public employment in Bonn has only resulted in a modest increase in private sector employment. Expressed as employment multipliers, the estimated treatment effects suggest that each additional public sector job reduces employment in industry by around 0.2 jobs while it creates just over one additional job in other parts of the private sector. We interpret our results in the context of a simple theoretical model which allows for productivity and amenity spillovers from public to private employment. Reduced form evidence suggests that the main mechanism behind our results is an increase in endogenous consumption amenities in Bonn while productivity in the private sector has at best been unchanged. A simple quantitative analysis of our theoretical model finds complementary results. While the best fit parameter for the estimated productivity spillovers of public employment is negative and close to zero, the best fit parameter for the estimated amenity spillovers of public employment is positive and much larger.

More broadly our results contribute to the debate of whether changes in the level of public employment are a viable policy instrument to support economically lagging regions. As our natural experiment involves the creation of a new federal government that naturally attracts diplomats, lobbyists and visitors, our estimated effects should be an upper bound for the positive spillover effect that additional public sector employment can generate in the private sector. Some of what we capture as amenity spillovers could, for example, be driven by political economy forces that direct additional government expenditure on cultural amenities to Bonn. This implies that increasing the number of more mundane types of public employment in lagging regions could have even smaller spillover effects on private sector activity in the targeted regions.

\section{Supplementary materials}

Supplementary material associated with this article can be found, in the online version, at doi:10.1016/j.jue.2020.103291. 


\section{CRediT authorship contribution statement}

Sascha O. Becker: Conceptualization, Methodology, Software, Validation, Formal analysis, Investigation, Data curation, Writing - original draft, Writing - review \& editing, Visualization, Supervision, Project administration, Funding acquisition. Stephan Heblich: Conceptualization, Methodology, Software, Validation, Formal analysis, Investigation, Data curation, Writing - original draft, Writing - review \& editing, Visualization, Supervision, Project administration, Funding acquisition. Daniel M. Sturm: Conceptualization, Methodology, Software, Validation, Formal analysis, Investigation, Data curation, Writing - original draft, Writing - review \& editing, Visualization, Supervision, Project administration, Funding acquisition.

\section{References}

Abadie, A., Diamond, A., Hainmueller, J., 2010. Synthetic control methods for comparative case studies: estimating the effect of California's tobacco control program. J. Am. Stat. Assoc. 105 (490), 493-505.

Abadie, A., Diamond, A., Hainmueller, J., 2015. Comparative politics and the synthetic control method. Am. J. Pol. Sci. 59 (2), 495-510.

Abadie, A., Gardeazabal, J., 2003. The economic costs of conflict: a case study of the Basque country. American Economic Review 93 (1), 113-132.

Acconcia, A., Corsetti, G., Simonelli, S., 2014. Mafia and public spending: evidence on the fiscal multiplier from a quasi-experiment. American Economic Review 104 (7), 2185-2209.

Adenauer, K., 1965. Erinnerungen 1945-1953. Deutsche Verlags-Anstalt, Stuttgart.

Ahlfeldt, G., Redding, S., Sturm, D., Wolf, N., 2015. The economics of density: evidence from the Berlin Wall. Econometrica 83 (6), 2127-2189.

Albouy, D., Lue, B., 2015. Driving to opportunity: local rents, wages, commuting costs and sub-metropolitan quality of life. J. Urban Econ. 89, 74-92.

Alesina, A., Danninger, S., Rostagno, M., 2001. Redistribution through public employment: the case of Italy. IMF Staff Papers 48 (3), 447-473.

Algan, Y., Cahuc, P., Zylberberg, A., 2002. Public employment and labour market performance. Economic Policy 17, 7-65.

Anderson, J., van Wincoop, E., 2004. Trade costs. J. Econ. Lit. 42 (3), 691-751.

Auricchio, M., Ciani, E., Dalmazzo, A., de Blasio, G., 2020. Life after public employment retrenchment: evidence from Italian municipalities. Journal of Economic Geography 20 (3), 733-782.

aus dem Moore, J.P., Spitz-Oener, A., 2012. Bye bye, G.I. - the impact of the U.S. military drawdown on local German labor markets. Humboldt University SFB 649 Discussion Paper DP2012-024.

Beaudry, P., Green, D.A., Sand, B., 2012. Does industrial composition matter for wages? a test of search and bargaining theory. Econometrica 80 (3), 1063-1104.

Bender, S., Haas, A., Klose, C., 2000. IAB employment subsample 1975-1995. Schmollers Jahrbuch [Journal of Applied Social Science Studies] 120, 649-662.

Bernard, A.B., Wagner, J., 1997. Exports and success in German manufacturing. Weltwirtsch. Arch. 133 (1), 134-157.

Black, D., McKinnish, T., Sanders, S., 2005. The economic impact of the coal boom and bust. The Economic Journal 115 (503), 449-476.

Boeri, T., Nicoletti, G., Scarpetta, S., 2000. Regulation and labour market performance. In: Galli, G., Pelkmans, J. (Eds.), Regulatory Reform and Competitiveness in Europe. Edward Elgar Publisher, Cheltenham UK, pp. 324-380.

Carrington, W.J., 1996. The Alaskan labor market during the pipeline era. Journal of Political Economy 104 (1), 186-218.

Chbib, R., 2017. Die Entwicklung des islamischen Religionsfeldes in Deutschland im Spannungsfeld muslimischer Neuzuwanderung und fortgeschrittener Einbürgerung. In: Ströbele, C., Gharaibeh, M., Middelbeck-Varwick, A., Dziri, A. (Eds.), Migration, Flucht, Vertreibung: Orte Islamischer und Christlicher Theologie. Verlag Friedrich Pustet, Regensburg.

Combes, P.-P., Duranton, G., Gobillon, L., 2019. The costs of agglomeration: house and land prices in French cities. Rev. Econ. Stud. 86 (4), 1556-1589.

Conley, T.G., Taber, C.R., 2011. Inference with 'difference in differences' with a small number of policy changes. Review of Economics and Statistics 93 (1), 113-125.

Daly, M.C., 1940. An approximation to a geographical multiplier. The Economic Journal 50 (198/199), 248-258.

Davis, M.A., Ortalo-Magné, F., 2011. Housing expenditures, wages, rents. Rev. Econ. Dyn. 14 (2), 248-261.

Deutscher Städtetag, 1931. Statistisches Jahrbuch der deutschen Städte. Deutscher Städtetag, Berlin.

Deutscher Städtetag, 1986. Statistisches Jahrbuch Deutscher Gemeinde. Deutscher Städtetag, Köln.

Deutscher Städtetag, 1988. Statistisches Jahrbuch Deutschen Gemeinden. Deutscher Städtetag, Köln.

Diamond, R., 2016. The determinants and welfare implications of us workers' diverging location choices by skill: 1980-2000. American Economic Review 106 (3), 479-524.
Faggio, G., 2019. Relocation of public sector workers: evaluating a place-based policy. J. Urban Econ. 111, 53-75.

Faggio, G., Overman, H., 2014. The effect of public sector employment on local labour markets. J Urban Econ 79, 91-107.

Faggio, G., Schlüter, T., vom Berge, P., 2018. Interaction of public and private employment: Evidence from a German government move. SERC Discussion Paper No. 229.

Feenstra, R.C., 1994. Zonal boundaries and access to Berlin. American Economic Review 84 (1), 157-177.

Feyrer, J., Mansur, E.T., Sacerdote, B., 2017. Geographic dispersion of economic shocks: evidence from the fracking revolution. American Economic Review 107 (4), 1313-1334.

Floehr, R., 1986. Bonn - die gekaufte Hauptstadt. Fleur, Krefeld.

Franklin, W.M., 1963. Zonal boundaries and access to Berlin. World Polit. 16 (1), 1-31.

Gartner, H., 2005. The imputation of wages above the contribution limit with the German IAB employment sample. FDZ Methodenreport. Institute for Employment Research.

Gemeinschaftsveröffentlichung der Statistischen Landesämter, 1991. Volkswirtschaftliche Gesamtrechnung der Länder, Heft 19. Statistisches Landesamt Baden Württemberg, Stuttgart.

Ghironi, F., Melitz, M.J., 2005. International trade and macroeconomic dynamics with heterogeneous firms. Quarterly Journal of Economics 120 (3), 865-915.

Glaeser, E.L., Kolko, J., Saiz, A., 2001. Consumer city. Journal of Economic Geography 1 (1), 27-50.

Gobillon, L., Magnac, T., 2016. Regional policy evaluation: interactive fixed effects and synthetic controls. Review of Economics and Statistics 98 (3), 535-551.

Handbury, J., Weinstein, D., 2015. Goods prices and availability in cities. Rev Econ Stud 82 (1), 258-296.

Helpman, E., 1998. The size of regions. In: Pines, D., Sadka, E., Zilcha, I. (Eds.), Topics in public economics: theoretical and applied analysis. Cambridge University Press, Cambridge, pp. 33-54.

Herdegen, G., 1992. Einstellungen Zur Deutschen Einheit. In: Weidenfeld, W., Korte, K.-R. (Eds.), Handwörterbuch zur Deutschen Einheit. Campus Verlag, Frankfurt am Main.

Hildebrand, G.H., Mace, A., 1950. The employment multiplier in an expanding industrial market: Los Angeles county, 1940-47. Rev. Econ. Stat. 32 (3), 241-249.

Jofre-Monseny, J., Silva, J.I., Vázquez-Grenno, J., 2020. Local labor market effects of public employment. Reg. Sci. Urban Econ. 82, 103406.

Kästner, F., 1949. Kriegsschäden: Trümmermengen, Wohnungsverluste, Grundsteuerausfall und Vermögensteuerausfall. Statistisches Jahrbuch deutscher Gemeinden, 37. Deutscher Städtetag, Köln.

Kaul, A., Klößner, S., Pfeifer, G., Schieler, M., 2017. Synthetic control methods: never use all pre-intervention outcomes together with covariates. mimeo.

Kettenacker, L., 1989. Krieg zur Friedensicherung: Die Deutschlandplanung der britischen Regierung während des Zweiten Weltkrieges. Vandenhoeck and Ruprecht, Göttingen.

Kline, P., Busso, M., 2013. Assessing the incidence and efficiency of a prominent place based policy. American Economic Review 103 (2), 897-947.

Kline, P., Moretti, E., 2014. Local economic development, agglomeration economies, and the big push: 100 years of evidence from the Tennessee Valley Authority. Quarterly Journal of Economics 129 (1), 275-331.

Krugman, P., 1991. Increasing returns and economic geography. Journal of Political Economy 99 (3), 483-499.

Lombardo, G., Ravenna, F., 2012. The size of the tradable and non-tradable sectors: evidence from input-output tables for 25 countries. Econ. Lett. 116 (3), 558-561.

Malchin, A., Voshage, R., 2009. Official firm data for germany. Schmollers Jahrbuch [Journal of Applied Social Science Studies] 129 (3), 501-513.

Moretti, E., 2010. Local multipliers. American Economic Review, Papers and Proceedings 100 (2), 1-7.

Moretti, E., 2011. Local labor markets. In: Card, D., Ashenfelter, O. (Eds.), Handbook of labor economics, 4b. Elsevier North Holland, Amsterdam, pp. 1238-1303.

Nakamura, E., Steinsson, J., 2014. Fiscal stimulus in a monetary union: evidence from U.S. regions. American Economic Review 104 (3), 753-792.

Neumark, D., Simpson, H., 2015. Place-based policies. In: Duranton, G., Henderson, V., Strange, W. (Eds.), Handbook of Regional and Urban Economics, 5. Elsevier, Amsterdam, pp. 1197-1287.

OECD, 2009. Government at a glance. OECD Publishing, Paris.

Redding, S.J., 2016. Goods trade, factor mobility and welfare. J. Int. Econ. 101, 148-167.

Redding, S.J., Sturm, D.M., 2008. The costs of remoteness: evidence from German division and reunification. American Economic Review 98 (5), 1766-1797.

Richardson, H.W., 1985. Input-output and economic base multipliers: looking backward and forward. J. Reg. Sci. 25 (4), 607-661.

Roback, J., 1982. Wages, rents and the quality of life. Journal of Political Economy 90 (6), 1257-1278.

Rosen, S., 1979. Wages-based indexes of Urban quality of life. In: Mieszkowski, P., Straszheim, M. (Eds.), Current Issues in Urban Economics. Johns Hopkins University Press, Baltimore.

Saiz, A., 2010. The geographic determinants of housing supply. Q. J. Econ. 125 (3), 1253-1296.

Statistisches Reichsamt, 1941. Die Steuerleistung der Finanzamtsbezirke in den Rechnungsjahren 1926 bis 1938. P. Schmidt, Berlin.

Thompson, G.E., 1959. An investigation of the local employment multiplier. Rev. Econ. Stat. 41 (1), 61-67.

Wise, M.Z., 1998. Capital dilemma: Germany's search for a new architecture of democracy. Princeton Architectural Press, New York. 